\title{
Estudo radiográfico e microscópico das lesões periapicais inflamatórias induzidas em ratos
}

\section{Lidiane de Castro Pinto}

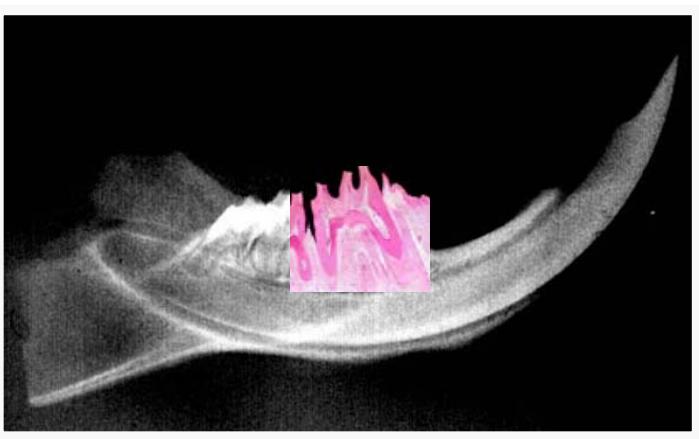

Dissertação apresentada à Faculdade de Odontologia de Bauru, da Universidade de São Paulo, como parte dos requisitos para a obtenção do título de Mestre em Odontologia, área de Patologia Bucal.

(Edição Revisada)

BAURU

2006 
Estudo radiográfico e microscópico das lesões periapicais inflamatórias induzidas em ratos

\title{
Lidiane de Castro Pinto
}

\begin{abstract}
Dissertação apresentada à Faculdade de Odontologia de Bauru, da Universidade de São Paulo, como parte dos requisitos para a obtenção do título de Mestre em Odontologia, área de Patologia Bucal.
\end{abstract}

(Edição Revisada)

Orientadora: Prof ${ }^{\mathrm{a}}$. Dra. Vanessa Soares Lara

\author{
BAURU
}

2006 


\section{Pinto, Lidiane de Castro}

P658e Estudo Radiográfico e Microscópico de Lesões Periapicais Inflamatórias induzidas em ratos / Lidiane de Castro Pinto - Bauru, 2006.

109p, il; $31 \mathrm{~cm}$

Dissertação (Mestrado) - Faculdade de Odontologia de Bauru, USP.

Orientadora: Profa. Dra. Vanessa Soares Lara.

Autorizo, exclusivamente, para fins acadêmicos e científicos, a reprodução total ou parcial desta dissertação, por processos fotocopiadores e outros meios eletrônicos.

Lidiane de Castro Pinto

Bauru, 31 de maio de 2006.

Aprovado pelo Comitê de Ética em Pesquisa da Faculdade de Odontologia de Bauru, USP.

Protocolo: 026/2003

Data: 02/10/2003 


\section{Lidiane de Castro Pinto}

24 de janeiro de 1968

Bauru - SP

$1986-1989$

1990

$1991-1999$

$2000-2002$

2002

$2003-2006$

$2005-2006$

$2005-2006$
Nascimento

Curso de Graduação em Odontologia

UNESP - Araraquara

Curso de Graduação em Psicologia

UNESP - Bauru

Atividade Clínica

Milão - Itália

Especialização em Endodontia

HRAC - USP - Bauru

Auxiliar de Ensino

Especialização em Endodontia

PROFIS - Bauru

Mestrado em Odontologia

Patologia Bucal - USP - Bauru

Coordenadora da Disciplina de Patologia Curso de Especialização em Endodontia UNINGÁ - Bauru

Atividade Clínica

Clínica Pró-Bucal

Rua Felício Soubihe 3-74 - Bauru 
2006

Docente

Curso de Atualização em Endodontia CEOMA - Marília

Associações

APCD - Bauru

$A B O$ - Bauru 
“... o que é mais importante?

O livro ou a sabedoria?..."

Sr. Gentileza 
Agradeço

à minha família:

Aos meus pais, Lidinei e Ary, pela vida, dedicação, amor incondicional e muitos momentos de felicidade!

Ao meu irmão Arley, por me fazer acreditar que um ideal vale à pena! 
Ao meu marido Ricardo, "por todo amor que houver nesta vida" e pela cumplicidade!

Ao meu filho Luca, pela felicidade eterna da sua vinda!

Às minhas meninas Giovita e Antonina, pela companhia, alegria e sabedoria! 
Aos meus sogros,

Battistutta e Heloísa, pelo apoio despretensioso, e por toda dedicação!

Aos meus cunhados, Adriane, Henrique e Lisa, pelo carinho e amizade verdadeira! Aos meus sobrinhos, Francesco e Gianluca, pela certeza que entenderão minha ausência! 
À minha Tia Lenir, aos meus primos Hedirley e Felipe, pelo carinho e disponibilidade sempre presentes!

Aos meus primos, Ronald, Heleyder e Henrique, pela compreensão, alegria, afeto e confiança!

Ao meu afilhado, João Victor, por ter me dado a oportunidade de saber o que é amar incondicionalmente! 


\section{AGRADECIMENTOS}

Agradeço aos professores desta banca pelo tempo disponibilizado na leitura e correção deste trabalho. A dedicação ao outro é uma qualidade nobre de alguns seres humanos.

Muito obrigada à querida orientadora Profa. Dra. Vanessa Soares Lara. Acredito que o papel de orientador científico seja uma tarefa difícil, importante e que deveria ser somente ocupada por pessoas como você: dignas acima de tudo. Agradeço também a vocês, Vinícios e Matheus por aquela sempre amizade eterna!

Obrigada aos professores da Patologia: Prof. Dr. Alberto Consolaro e Profa. Dra. Denise Tostes Oliveira. E em especial, ao também amigo, Prof. Dr. Luís Antônio de Assis Taveira.

Aos funcionários Maria Cristina Carrara Felipe, Richard Medeiros, Osiel Pereira Cabreira, Sr. Valdir João Afonso pela disponibilidade e cortesia que sempre me dedicaram.

À querida Fátima Aparecida Silveira (Fatiminha) pela sua colaboração indispensável no trabalho histotécnico desenvolvido e sobretudo, pelas suas palavras gentis, pelas horas agradáveis passadas no laboratório, enfim, por ter sido tão amiga e especial! 
Aos colegas da pós-graduação: Andrea, Bethânia, Christian, Érick, João Adolfo, Leda, Luciana, Maria Fernanda, Maria Renata, Marta, Patrícia, Renata Falchete, Renata Consolaro, Renato, Suzana e Tiago. Foram momentos agradáveis e de alegria.

À você Bethânia, por termos acreditado juntas que era possível!

De forma especial, agradeço à colega e amiga Camila Rodini, pela coloração e montagem de todas as lâminas deste trabalho, pela revisão do texto e confecção do Abstract. Sua dedicação é inesquecível, assim como a tua alegria de viver. Se o Mestrado me proporcionou um grande presente, com certeza, este foi tua amizade. Obrigada também a toda tua família: Bruno, Elaine e Carol, por serem pessoas assim tão queridas.

À querida colega e amiga Rosário, obrigada pela colaboração no exame das lâminas deste trabalho e mais ainda, pela nossa convivência divertida e intensa. Talvez, você não tenha a dimensão do quanto me ajudou, mas pode ter certeza, que nunca me esquecerei!

Ao companheiro de pesquisa Mauro Vinícius Corotti, pelo tempo que passamos juntos no laboratório, pela colaboração e por sua forma tranqüila de ser.

À amiga e colega Aline Carvalho Batista, pelo seu jeito carinhoso e humilde que esconde uma grande capacidade intelectual. 
Aos colegas pós-graduandos dos demais Departamentos.

À Tânia Mary Cestari, pela sua colaboração desinteressada; você é uma pessoa diferente, especial e de uma capacidade incrível.

Aos funcionários da biblioteca sempre disponíveis a nos ajudar. Em especial, a Sra. Jane com seu sorriso e gentileza.

Aos funcionários do Biotério da Faculdade de Odontologia de Bauru, em especial nas pessoas de Erasmo Gonçalves da Silva e Luiz Carlos da Silva pelo acolhimento e disponibilidade. Principalmente, aos "ratinhos"...

Aos funcionários da seção de pós-graduação pelo serviço prestado. Em especial, à "Meg”, pela sua disponibilidade.

Agradeço ao Prof. Dr. Casati pelo seu exemplo que me impulsionou à pesquisa. Grande homem e professor do nosso tempo!

Às amigas Profa. Dra. Izabel Maria Marchi de Carvalho e Dra. Silvia Graziadei pelo incentivo e demonstração de honestidade.

Ao Prof. Dr. Celso Kenji Nishiyama por ter me encorajado na escolha do Mestrado e também pela confiança depositada. 
Ao Prof. Dr. Renato Leonardo pela disponibilidade e incentivo na carreira acadêmica e acima de tudo por demonstrar que o sucesso nem sempre faz esquecer dos velhos amigos.

Ao Prof. Dr. Fábio Perassi pelo seu entusiasmo e exemplo como endodontista.

Ao Prof. Dr. Carlos Alberto Benatti, por ter me mostrado o "mundo patológico" ainda nos tempos da graduação.

À minha orientada Christianna de Freitas, pela compreensão da minha ausência.

Aos meus colegas de consultório: Dr. Newson Xavier, Dra. Maria Célia Arieta e Dra. Maria Helena Vasconcelos pela paciência e compreensão da minha indisponibilidade. À Karina Pandolfi, pelo carinho e ajuda constante. Aos meus pacientes, que mesmo diante da minha ausência se mantiveram fiéis. Obrigada pela confiança.

À minha amiga Lílian Jacob por tantos conselhos úteis. Por ter me proporcionado muitos momentos de descontração.

Às minhas amigas Thaís Accorsi, Valéria Gelani e Renata Pardini, pelo constante incentivo e carinho. 


\section{AGRADECIMENTOS INSTITUCIONAIS}

À Direção da Faculdade de Odontologia de Bauru (USP), na pessoa de sua Excelentíssima Diretora, Profa. Dra. Maria Fidela de Lima Navarro.

À Comissão de pós-graduação da FOB-USP, na pessoa do Presidente, Prof. Dr. José Carlos Pereira.

Ao Departamento de Estomatologia da Faculdade de odontologia de Bauru, na pessoa do Chefe Prof. Dr. Luis Eduardo Chinelatto.

À CAPES e FOB-USP pelo apoio financeiro. 


\section{SUMÁRIO}

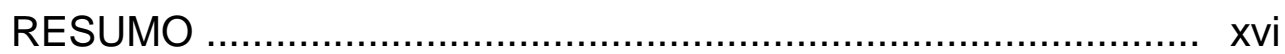

1 - INTRODUÇÃO E SÍNTESE BIBLIOGRÁFICA ................... 1

1.1 - Estudo da lesão periapical inflamatória em humanos............ 3

1.2 - Estudo da lesão periapical inflamatória em modelos

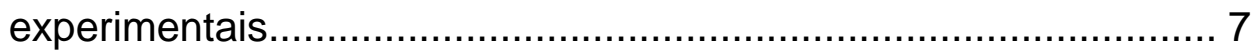

1.3 - Estudo radiográfico da lesão periapical inflamatória ............. 11

2 - PROPOSIÇÃO ................................................................ 17

3 - MATERIAL E MÉTODOS....................................... 19

3.1 - Animais ......................................................... 20

3.2 - Indução experimental da lesão periapical inflamatória........ 21

3.3 - Sacrifício dos animais e manipulação dos espécimes ....... 22

3.4 - Obtenção e análise das imagens radiográficas.................. 23

3.5 - Análise microscópica subjetiva.................................... 27

4 - RESULTADOS........................................................... 33

4.1 - Grupos Controle ................................................... 35

4.2 - Período experimental de 3 dias (grupo 1)..................... 36

4.3 - Período experimental de 7 dias (grupo 2)...................... 37

4.4 - Período experimental de 14 dias (grupo 3)...................... 37

4.5 - Período experimental de 21 dias (grupo 4).................... 38

4.6 - Período experimental de 30 dias (grupo 5)..................... 39

4.7 - Período experimental de 60 dias (grupo 6)..................... 40

4.8 - Período experimental de 90 dias (grupo 7).................... 40

4.9 - Período experimental de 120 dias (grupo 8).................... 41

4.10 - Período experimental de 180 dias (grupo 9).................. 42

5 - DISCUSSÃO.......................................................... 51

6 - CONCLUSÕES........................................................ 59

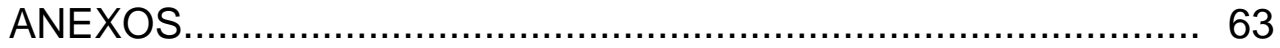

REFERÊNCIAS BIBLIOGRÁFICAS.................................. 91

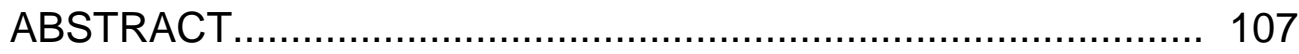





\section{RESUMO}

As lesões periapicais desenvolvem-se como uma resposta defensiva dos tecidos periapicais frente à infecção bacteriana e a irritantes químicos, térmicos e/ou mecânicos. Neste estudo, analisamos a evolução da lesão periapical induzida experimentalmente em seus aspectos radiográficos e microscópicos; a fim de caracterizar seu desenvolvimento em cada fase de progressão. Para este fim, ratos foram submetidos à indução da lesão periapical por meio de abertura coronária do primeiro molar inferior esquerdo e exposição à cavidade bucal, permitindo a contaminação bacteriana. Os espécimes foram avaliados em períodos de 3 a 180 dias após a indução da lesão periapical. De acordo com nossos resultados, as lesões periapicais induzidas apresentam infiltrado inflamatório predominantemente polimorfonuclear nos períodos de até 60 dias após a indução, apresentando, em seus períodos posteriores, infiltrado inflamatório predominantemente mononuclear. Radiograficamente, as lesões periapicais aumentaram nitidamente entre os períodos experimentais de 7 e 14 dias após a indução, expandindo em menor proporção nos períodos de 14 a 60 dias e se estabilizaram aos 60 e 120 dias após a indução. Analisando os diferentes aspectos observados em nossos resultados, podemos concluir que, a partir do primeiro período avaliado (3 dias), os aspectos radiográficos foram concordantes com os microscópicos, e que a presença do aspecto microscópico cavidade cística - e do aspecto radiográfico - rarefação óssea localizada - na região apical do primeiro molar inferior esquerdo foi observada a partir do período de 7 dias após a indução. A fase ativa de evolução da lesão apical, com importante destruição óssea, relacionou-se com a predominância de um infiltrado inflamatório polimorfonuclear, enquanto que o infiltrado apresentava-se predominantemente mononuclear na fase de estabilização da lesão induzida. Ainda, os aspectos radiográficos referentes à lesão induzida em ratos apresentamse semelhantes àqueles da doença periapical inflamatória em humanos; assim, o modelo animal utilizado mostrou-se satisfatório para o estudo da evolução de lesões periapicais inflamatórias. 
1 - INTRODUCÃO E SÍNTESE BIBLIOGRÁFICA 


\section{1 - INTRODUÇÃO E SÍNTESE BIBLIOGRÁFICA}

As reações periapicais inflamatórias ocorrem após a alterações pulpares decorrentes de agentes mecânicos, físicos, químicos e/ou bacterianos ${ }^{51}$, cuja evolução pode variar dependendo da intensidade do estímulo agressor, das condições anatomoclínicas da coroa dentária e do ápice radicular e do estado de higidez dos tecidos periapicais ${ }^{37}$. A etiopatologia das lesões periapicais está intimamente ligada à infecção bacteriana oriunda do canal radicular $^{34}$. A presença de patógenos no interior do sistema de canais pode induzir uma resposta defensiva local do hospedeiro que culmina com o desenvolvimento de lesões periapicais ${ }^{29}$. A invasão bacteriana na polpa dentária é, então, responsável pela infecção pulpar e necrose; sendo que o desenvolvimento da infecção com predomínio de bactérias anaeróbias no canal radicular causa destruição tecidual na região periapical e induz a uma resposta inflamatória local $^{4}$.

Atualmente, a participação de fenômenos imunopatológicos na gênese das lesões periapicais está comprovada ${ }^{66,68}$. A reação ao estímulo oriundo do canal, embora importante para localizar e destruir o antígeno resulta, freqüentemente, em destruição dos tecidos periapicais. A doença periapical, então, seria um subproduto da bem sucedida defesa imunológica do hospedeiro ${ }^{63}$. 


\section{1 - Estudo da lesão periapical inflamatória em humanos}

A resposta inflamatória associada à patologia periapical é semelhante àquela em qualquer outra parte do corpo. Portanto, se as bactérias e seus produtos alcançam a área periapical, há o recrutamento e a interação com polimorfonucleares neutrófilos e macrófagos. Se o processo continua, células inflamatórias crônicas, especialmente linfócitos, plasmócitos e macrófagos, cercam os agentes irritantes. A partir de então, os fenômenos imunológicos desempenham um papel importante na tentativa de eliminar o agente agressor, podendo culminar com a formação da lesão periapical e conseqüente reabsorção óssea. As bactérias viáveis, os produtos bacterianos e as alterações dos tecidos locais podem iniciar e propagar a doença periapical, sendo que a resposta imunológica tem grande importância na manutenção da inflamação local e na progressão da doença periodontal ${ }^{66}$. Se o agente irritante for removido, isto é, se o tratamento endodôntico for realizado, então, provavelmente ocorrerá a cura ${ }^{8}$.

A interação dinâmica entre fatores microbianos e de defesa do hospedeiro na interface entre a polpa radicular infectada e o ligamento periodontal, resulta em inflamação local, reabsorção de tecidos duros, destruição de outras estruturas periapicais e eventual formação de periodontite apical, comumente referida como lesão periapical ${ }^{43}$.

As lesões periapicais crônicas são classificadas, pela maioria dos autores $^{7,8,9,34,54}$, em granuloma periapical e cisto radicular ou cisto periodontal apical. Os granulomas periapicais são ricamente celularizados e circundados por uma cápsula fibrosa, sendo o infiltrado inflamatório caracterizado pela 
presença de células do sistema mononuclear fagocitário, linfócitos, plasmócitos e eosinófilos ${ }^{48}$. O granuloma periapical reflete uma lesão inflamatória crônica granulomatosa, de longa duração com caráter predominantemente proliferativo e induzida geralmente por agentes agressores de origem bacteriana advindos do canal radicular. Microscopicamente, pode-se observar a presença de cordões e ilhotas de células epiteliais odontogênicas, originadas dos restos epiteliais de Malassez, presença de células espumosas ou pseudoxantomatosas representadas por macrófagos carregados de lipídeos, corpúsculos hialinos de Russel representados por formações eosinofílicas esféricas ou em forma de "cachos de uva" e, ainda, de cristais de colesterol. Radiograficamente, o acúmulo de macrófagos no granuloma periapical traduzse em uma lesão radiolúcida que se apresenta como uma rarefação óssea bem definida, delimitada por uma delicada linha radiopaca descontínua. Associada ao granuloma periapical, pode ocorrer reabsorção dentária apical, que geralmente é notada radiograficamente ${ }^{9}$. De fato, as periapicopatias resultam em perdas ósseas e destruição tecidual envolvendo significante atividade enzimática, o que pode, ainda, resultar em destruição de toda uma área de tecido conjuntivo não mineralizado ${ }^{35,55}$.

O cisto periodontal apical ou cisto periapical apresenta, radiograficamente, uma área radiolúcida uniforme, arrendodada ou oval, bem definida e, em grande número de vezes, circundada por halo radiopaco, fruto da esclerose óssea reacional que envolve o processo ${ }^{54}$. Os cistos periodontais apicais são caracterizados como uma lesão inflamatória de crescimento não invasivo, que apresenta uma cavidade preenchida por material fluido ou semifluido limitada 
por epitélio pavimentoso estratificado e suportada por uma cápsula de tecido conjuntivo compatível com granuloma e fibrose superficial ${ }^{65}$. Ainda no revestimento epitelial, notam-se, microscopicamente, acúmulos superficiais de corpúsculos hialinos de Rushton, caracterizados pela conformação circunferencial ou ovalada, podendo envolver até a camada espinhosa ${ }^{9}$. Com relação à terapia, alguns autores descrevem que o tamanho da lesão pode ser determinante na escolha do tratamento endodôntico convencional ou cirúrgico ${ }^{5}$, sendo que, na maioria das vezes, o tratamento convencional do canal radicular implica na diminuição ou desaparecimento radiográfico de 85 a 90\% das áreas radiolúcidas apicais ${ }^{39,44}$.

A diferença radiográfica entre o granuloma periapical e o cisto periodontal apical não pode ser definida precisamente. CASATI-ALVARES, MARZOLA e FREITAS $^{7}$ (1971) compararam a freqüência de cistos periodontais apicais em relação aos granulomas periapicais, quando diagnosticados pelos exames radiográficos e histopatológicos, bem como verificaram a precisão do diagnóstico radiográfico, quando comparado com o histopatológico. Os autores concluíram que o número de cistos periodontais apicais $(16,1 \%)$ foi menor do que o de granulomas periapicais $(89,9 \%)$ e que, quando comparado com o diagnóstico histopatológico, o laudo de um radiologista experimentado foi compatível em $83,1 \%$ dos casos, sendo o maior número de erros ocorridos na maxila. Outros autores ${ }^{44,46}$, a partir de análise radiográfica e microscópica de lesões periapicais apensas em ápices de dentes extraídos, também verificaram que o granuloma periapical foi a lesão mais freqüentemente observada. 
Alguns estudos radiográficos têm procurado diferenciar granuloma periapical e cisto periodontal apical, mas ainda sem sucesso ${ }^{4}$. Radiograficamente, ainda não é possível estabelecer definitivamente um diagnóstico diferencial entre ambas as lesões periapicais crônicas. Atualmente, um meio de diagnóstico diferencial de tais lesões é a tomografia computadorizada helicoidal; porém é indiscutível sua inviabilidade clínica pela sua relação custo-benefício ${ }^{71}$.

Dentes portadores de processos apicais crônicos apresentam, freqüentemente, alguma forma de reabsorção radicular, que pode afetar o cemento e/ou dentina radicular $^{4}$ e, de acordo com FERLINI ${ }^{18}$ (1999), a mesma pode ser detectada através do estudo microscópico em $94,44 \%$ dos casos, em contraste com a detecção radiográfica, que ocorreu somente em 36,11\% dos casos.

O estudo das características microscópicas dos granulomas e cistos periapicais, a partir de material de biópsias de cirurgias parendodônticas e de dentes extraídos, tem sido bastante explorado ${ }^{4,18,34,44,46}$. Muitas pesquisas sobre lesões periapicais crônicas foram realizadas em humanos, limitando-se, portanto, ao estudo destas lesões já instaladas, caracterizadas radiografica e microscopicamente, porém de forma estática. O estudo da evolução das lesões periapicais, como por exemplo, a partir de lesões induzidas experimentalmente, vem contribuir para a caracterização e o entendimento da sua patogênese e dos fatores envolvidos no recrutamento e ativação das células inflamatórias, considerando-se diferentes tempos de evolução. Devido à limitação da realização desse tipo de pesquisa em humanos, tem-se valido de estudos realizados em animais. 


\section{2 - Estudo da lesão periapical inflamatória em modelos experimentais}

Os dentes molares de ratos são freqüentemente utilizados em pesquisas na área de endodontia como modelo experimental ${ }^{23,58}$, entretanto, existe pouca informação quanto sua fisiologia ${ }^{27}$, anatomia e, ainda, quanto à avaliação dos resultados obtidos em pesquisas e suas variáveis ${ }^{38}$.

Para se utilizar do rato como modelo experimental, é necessário o conhecimento detalhado da anatomia dentária e das suas estruturas adjacentes. O primeiro molar inferior apresenta coroa dentária de forma trapezoidal, sendo mais longa no sentido mesio-distal, com sete cúspides denominadas de acordo com a localização: mesio-lingual, mesio-vestibular, centro-mesio-lingual, centro-mesio-vestibular, centro-disto-lingual, centro-distovestibular e distal. A cúspide distal localizada centralmente é muito pequena, mas de fácil distinção ${ }^{26}$. Quanto à anatomia radicular do primeiro molar inferior do rato, temos a presença de quatro raízes que podem ser designadas de acordo com suas posições: mesial, centro-lingual, centro-vestibular e distal. As raízes mesial e distal estão situadas na linha média, enquanto as centrais estão lado a lado, uma mais para vestibular e a outra para lingual. A raiz mesial é a mais longa delas e apresenta secção transversal oval, com seu longo eixo inclinado de mesio-lingual para disto-vestibular, e o forame apical é posicionado centralmente. A raiz distal é um pouco mais ampla que a raiz mesial e sua secção transversal apresenta forma de "rim", achatada no sentido mesio-distal, sendo o forame apical inclinado para a face vestibular. A raiz centro-vestibular é a menor delas e sua secção transversal é oval. A raiz centro-lingual é a mais arredondada e divergente e, em muitos casos, 
encontra-se fusionada com a raiz distal na região cervical. Em relação à câmara pulpar, esta usualmente reflete a anatomia coronária. Existem três cornos pulpares abaixo das cúspides principais, de igual altura e respectivos às cúspides mesial e distal. Em um corte transversal da câmara pulpar, pode-se observar uma ampla cavidade na região cervical, porém, em direção apical, é possível observar a presença de quatro raízes e seus respectivos canais radiculares, cada um com suas conformações ${ }^{56}$.

Espécimes cirúrgicos derivados de humanos são cada vez mais difíceis de se obter, sendo os estudos experimentais de grande importância para o estudo das lesões periapicais. Entre os animais utilizados neste tipo de estudo, estão macacos e cães, porém com limitações quanto à obtenção, manutenção e alto custo. Para sanar estas dificuldades, desenvolveu-se um protocolo de estudo de terapia endodôntica em canais de $\operatorname{ratos}^{16}$. Assim, a indução da lesão periapical em ratos possibilita o estudo da cinética desta lesão e torna-se mais viável $^{10,57,59}$. EURASQUIN e MURUZÁBAL ${ }^{16}$ (1967) avaliaram a reação periapical frente à exposição pulpar em 40 ratos, com idade de 30 a 180 dias, sendo que os animais foram sacrificados 24 horas e 60 dias após a exposição pulpar. Os autores concluíram que a reação periapical provocada pela exposição pulpar segue, no rato, a mesma evolução que no homem, cão e hamster, ou seja, resulta na formação de granuloma periapical. Afirmaram, ainda, que, no estudo experimental da biologia endodôntica, o método de indução utilizado permite o estudo em animais de fácil obtenção e isogênicos, o que possibilita maior credibilidade dos resultados. 
O trabalho de KAKEHASHI, STANLEY e FITZGERALD ${ }^{28}$, em 1965, demonstrou a etiologia microbiana das periapicopatias. Os autores submeteram ratos não contaminados (germ free) e convencionais a exposições pulpares ao meio bucal. No grupo de 21 animais germ free, não houve necrose pulpar ou abscesso periapical. Em contrapartida, todos os animais convencionais mostraram necrose pulpar, alguns com formação de abscesso.

A etiopatogenia das lesões periapicais implica na participação do sistema imunológico ${ }^{67}$, em resposta aos antígenos que entram nos tecidos periapicais através do sistema de canais radiculares. Então, as lesões periapicais representam uma resposta imunológica local provocada por infecção bacteriana na polpa dentária ${ }^{62}$. A relação da imunologia com a endodontia foi proposta por DIETZ ${ }^{13}$ (1952), que demonstrou, em animais, que a injeção subcutânea de infiltrados preparados a partir do conteúdo de canais radiculares causam reação imunológica, evidenciando indiretamente que, nas lesões periapicais, podem ocorrer reações de hipersensibilidade.

Na presença da lesão periapical induzida experimentalmente em ratos, em que nenhum tratamento endodôntico foi instaurado e, portanto, não removida a causa da lesão, há a persistência e o aumento da lesão periapical ${ }^{12}$.

Nas diferentes fases do desenvolvimento da lesão periapical, observam-se linfócitos T auxiliares ou T helper como o subtipo celular predominante durante a fase ativa da lesão, enquanto que na fase crônica predominam os linfócitos T supressores, sugerindo assim que a atividade mediada por essas células poderia estar envolvida na destruição óssea em lesões periapicais induzidas em ratos $^{59}$ 
As lesões periapicais induzidas experimentalmente em ratos, desenvolvem-se rapidamente entre os dias 0 e 15 (fase ativa) e mais lentamente nos períodos subseqüentes (fase crônica) ${ }^{58}$, quando a microbiota anaeróbia e gram-negativa, semelhante àquela observada em humanos, rapidamente se estabelece. Essas lesões contêm um infiltrado celular inflamatório misto consistindo de linfócitos T, neutrófilos, linfócitos B, macrófagos e plasmócitos. Linfócitos $T$ auxiliares predominam durante a fase ativa, enquanto que as células T supressoras são mais freqüentes na fase crônica. Extratos das lesões periapicais apresentaram atividade de reabsorção óssea, cujos mais altos níveis estavam presentes quando as lesões estavam se expandindo ${ }^{57}$.

Entretanto, em outros estudos, as lesões periapicais induzidas em molares de ratos apresentavam predomínio de macrófagos em todos os períodos experimentais. O número de linfócitos aumentou antes do início da fase ativa da lesão ${ }^{31}$.

Radiograficamente, as lesões periapicais induzidas em ratos apresentam áreas radiolúcidas correspondentes às lesões ${ }^{3}$, após um período de $10^{58}$ a 15 dias da exposição pulpar ao meio bucal, mantendo-se estáveis entre 15 e 30 dias, sofrendo um aumento após este período e estabilizando-se após 90 dias ${ }^{58}$. Até os 15 dias, há uma progressão rápida com alto índice de perda óssea, caracterizando a fase aguda da lesão, e após este período há regressão e estabilização indicando a fase crônica da lesão periapical ${ }^{10,73}$. Outros autores, observaram áreas radiolúcidas indicando lesão periapical, a partir do $5^{\circ}$ dia após a indução experimental da lesão periapical em ratos como modelos 
experimentais, notando ainda o aumento significativo da lesão num período de 5 a $20 \operatorname{dias}^{36}$.

\section{3 - Estudo radiográfico da lesão periapical inflamatória}

A avaliação do tratamento endodôntico, seja em estudos científicos ou mesmo nas suas diversas fases clínicas, se faz principalmente através de radiografias $^{3,41}$. Esta é, então, uma ferramenta indispensável e de grande importância para a especialidade da endodontia ${ }^{22}$, além de ser um método seguro para a saúde geral do indivíduo e das estruturas dentárias, devida a sua baixa dose de radiação ${ }^{17}$.

Os resultados da maioria dos estudos endodônticos, relatando sucesso ou insucesso da terapia instituída, são baseados na interpretação de radiografias periapicais do dente tratado ${ }^{22}$.

Muitas pesquisas estão sendo desenvolvidas e ganham aceitação clínica tão quanto evidentes são suas vantagens ${ }^{21}$. A radiologia odontológica se inclui neste contexto, já que o aperfeiçoamento de suas técnicas reflete uma preocupação com a melhoria na qualidade da imagem radiográfica associada à redução da dose de radiação ao paciente, objetivando um correto diagnóstico ${ }^{6}$. Atualmente, temos a possibilidade de realizar um estudo radiográfico, basicamente, de duas formas. Primeiro, utilizando um sistema radiográfico baseado na presença da película radiográfica, onde o filme serve para detectar, armazenar e expor a informação. Segundo, é possível utilizar um outro sistema, porém sem a presença do filme, conhecido por radiografia digital direta (DDR), onde as funções de detecção, armazenagem e exposição da 
informação são realizadas por um sensor, um computador e um monitor. A questão é se este sistema será benéfico o suficiente para justificar a substituição da película radiográfica, ou existe somente a crença de inovação do desenvolvimento radiológico ${ }^{40}$.

Outra possibilidade de uso destes sistemas é a hibridização, ou seja, a imagem radiográfica obtida através de digitalização de uma imagem convencional, que também deve ser discutida ${ }^{21}$.

Muitos estudos estão avaliando o uso do sistema radiográfico sem filme tanto para a detecção de cárie como na endodontia $20,32,72$.

O maior benefício da radiografia digital direta (DDR), ou seja, com o sistema de sensor direto sem o uso de filmes é a capacidade de produzir a imagem instantaneamente, sem a necessidade do processamento convencional da película radiográfica ou da câmara escura. Além do mais, a dose de radiação neste sistema é menor, justificada por apresentar um sensor do tamanho do dente e, portanto, de menor dimensão do que a película radiográfica ${ }^{70}$, vantagem considerável especialmente para o tratamento endodôntico. Aliado à facilidade de armazenamento das imagens e à possibilidade destas serem transmitidas eletronicamente para consultoria ${ }^{6,21}$, também as imagens obtidas por DDR podem ser impressas ${ }^{40}$.

Como desvantagem do sistema digital direto devemos citar principalmente o alto custo, assim como ocorre na tomografia helicoidal computadorizada ${ }^{71}$ que, no entanto, apresenta vantagem por não ser um método invasivo e ainda possibilitar a quantificação exata do volume da lesão periapical, quando presente $^{3,15,30}$. Alguns estudiosos afirmam que as maiores desvantagens do 
sistema DDR são o tamanho do sensor, o limite de alcance da dose irradiada e a qualidade inferior da imagem produzida quando comparada com a convencional $^{14,42}$. Outra desvantagem que não deve ser desconsiderada está relacionada à fidelidade da imagem, uma vez que esta pode ser facilmente manipulada ou fraudada mais facilmente quando se utiliza o sistema digital ${ }^{22}$, o que legalmente pode ser inviável ${ }^{2}$.

No entanto, a grande maioria dos estudos demonstra não haver diferença estatisticamente significativa na comparação entre o método convencional e a radiografia digital, quando analisada a eficácia da interpretação radiográfica $20,32,40,60,70,72$.

No sistema de radiografia convencional, ou seja, com a presença do filme radiográfico, identificamos algumas vantagens em relação ao sistema de radiografia digital direta, como, por exemplo, a grande familiaridade que os profissionais interessados já possuem com este sistema, não requerendo conhecimento adicional do operador ou mesmo calibração para um novo método $^{18}$. Ainda, a radiografia convencional possui um custo conhecido e bastante acessível.

Com a introdução da imagem digital na radiologia odontológica, vários trabalhos surgiram com o objetivo de comparar o filme convencional com os diferentes sistemas de captação e digitalização da imagem. A interpretação radiográfica de imagens radiográficas digitalizadas é um método que facilita o diagnóstico ${ }^{6}$.

Muitos fatores são importantes quanto à interpretação radiográfica, principalmente na endodontia, entre eles, a elaboração de um diagnóstico 
preciso, baseado em outros dados analisados conjuntamente com a radiografia, seja ela digital direta ou convencional. O diagnóstico não pode ser realizado sem outras informações; indiscutivelmente, não pode ser feito apenas radiograficamente, embora a radiografia seja um excelente auxiliar clínico em muitos critérios, até mesmo, quanto à terapêutica ${ }^{6,7}$. Portanto, deve-se considerar, por exemplo, as características nosológicas da doença, a anamnese, bem como os dados epidemiológicos e clínicos que são tão importantes quanto os achados radiográficos ${ }^{21}$.

Quando do uso das radiografias convencionais em trabalhos científicos, devese considerar o tipo de filme empregado, a técnica de processamento, o aparelho de raios- $x$ e a quilovoltagem ${ }^{11}$, bem como o tempo de exposição dos raios-X e a habilidade do profissional na interpretação da imagem radiográfica ${ }^{6}$. Em 1919, oito segundos de exposição eram necessários para se radiografar um molar superior de um adulto ${ }^{49}$, tempo sensivelmente diminuído hoje. Em 1981, o filme KODAK Ekta-speed foi comercialmente disponibilizado, com a promessa de ser duas vezes mais rápido que o filme KODAK Ultra-speed e, conseqüentemente, reduzir a dose de radiação pela metade. De acordo com HOLTZMANN ${ }^{24}$, o filme Ekta-speed possui maior granulação e menor definição de imagem quando comparado com o Ultra-speed ${ }^{19}$, porém sem diferença estatisticamente significantiva ${ }^{24}$. Por outro lado, outros autores consideram o filme Ultra-speed superior ao Ekta-speed em termos de contraste, qualidade de imagem e alta satisfação ${ }^{33,64}$. Com a evolução dos tipos de filmes radiográficos e dos estudos na área de radiologia, grande importância passou a ser dada à 
diminuição da dose de radiação, que deve ser considerada quando no uso clínico.

Quanto à avaliação específica de lesões periapicais induzidas em ratos, por meio de radiografias, foi observado o aparecimento de áreas radiolúcidas correspondentes às lesões ${ }^{3}$ após um período de 5 dias $^{36}$ da exposição pulpar ao meio bucal, havendo aumento significativo da lesão num período de 5 a 20 dias $^{36}$. Outros autores observaram áreas radiolúcidas indicando lesão periapical a partir de $10^{58}$ a 15 dias após a indução experimental da lesão periapical em ratos, mantendo-se estáveis entre 15 e 30 dias, sofrendo um aumento após este período e estabilizando-se após 90 dias, ${ }^{58}$.

Os trabalhos já realizados, na intenção de determinar as características das lesões periapicais em ratos, deixam uma lacuna quanto à correlação dos achados radiográficos com os microscópicos. Além disso, sabendo-se que no decorrer da evolução destas lesões podem-se observar modificações morfológicas significativas em períodos mais tardios, torna-se importante a avaliação microscópica e radiográfica dos tecidos periapicais e suas adjacências em períodos experimentais mais longos. Sendo assim, pretendemos neste trabalho, caracterizar in vivo as várias fases de evolução das lesões periapicais induzidas em molares de ratos, num período de 3 a 180 dias, correlacionando os achados radiográficos e os microscópicos. 
2- PROPOSICCÃO 


\section{2 - PROPOSIÇÃO}

No presente trabalho, por meio do estudo de lesões periapicais induzidas experimentalmente em ratos, propusemo-nos a:

- Analisar a evolução da lesão periapical em seus aspectos radiográficos e microscópicos aos 3 até 180 dias após a indução,

- Correlacionar os aspectos radiográficos com os microscópicos observados nos diferentes períodos, e

- Avaliar o modelo experimental para o estudo da evolução de lesões periapicais inflamatórias. 
3 - MATERIAL E MÉTODOS 


\section{3 - MATERIAL E MÉTODOS}

Este estudo teve sua parte experimental desenvolvida conjuntamente com o trabalho de pesquisa do cirurgião-dentista Mauro Vinícius Corotti ${ }^{10}$, pertencente ao curso de Mestrado em Odontologia, área de concentração Biologia Oral, sob orientação do Prof. Dr. José Mauro Granjeiro, Departamento de Ciências Biológicas, FOB - USP.

\section{1 - Animais}

Foram utilizados 49 ratos da linhagem Wistar (Rattus norvegicus albinus), machos, com peso entre 150 e $200 \mathrm{~g}^{30}$ (aproximadamente 45 dias de idade ${ }^{56}$ ), sendo 45 animais submetidos à indução experimental de lesão periapical e 4 animais utilizados como controle totalmente negativo de acordo com trabalhos prévios $^{28,61}$.

Os ratos foram mantidos em condições ambientais no Biotério da Faculdade de Odontologia de Bauru (FOB-USP) e alimentados com ração granulada comercial Labina (Purina) e água ad libitum. 


\section{2 - Indução experimental da lesão periapical inflamatória}

A manipulação animal seguiu o protocolo aprovado pelo COBEA (Colégio Brasileiro de Experimentação Animal) e pela Comissão de Ética no Ensino e Pesquisa em Animais da FOB/USP (Prot. No 26/2003 - anexo 1). Os animais, no tempo zero (45 dias de idade), foram anestesiados utilizando um anestésico geral (Dopalen $®)$ e um relaxante muscular (Anasedan $®$ ), misturados na proporção 1:1. A punção intramuscular (parte interna da coxa traseira ${ }^{12}$ ) foi realizada com seringa descartável para insulina com $0,1 \mathrm{ml}$ da mistura, calculados de acordo com a instrução do fabricante dos medicamentos, observando-se o peso dos animais.

Uma vez aplicada a anestesia e após um período de 2 a 3 minutos, os animais apresentavam-se sonolentos e indiferentes ao ambiente externo, persistindo em estado sedativo por cerca de uma hora e trinta minutos, tempo mais que suficiente para o ato da abertura coronária. Os animais foram, então, acomodados em uma mesa operatória especial ${ }^{52}$ que possibilita a contenção do animal com a boca aberta, no entanto sem machucá-lo. Em seguida, os animais foram submetidos à exposição pulpar ${ }^{16,28,29,31,57,59,62}$ no primeiro molar inferior $^{56}$ do lado esquerdo, com broca de aço carbide multilaminada \# 1/2 (Jota Switzerland) montada em micromotor $^{57}$ (Kavo L-Motor 181DB intramatic e contra-ângulo Kavo 20 - Western German) em baixa rotação. A broca foi introduzida na fossa distal ${ }^{61}$, situada mesialmente à cúspide distal na face oclusal do dente ${ }^{56}$, na profundidade de cerca de $1 \mathrm{~mm}$, tendo-se o cuidado de não perfurar a furca. Com lima K \#08 (Maillefer - Dentisply), delimitada com cursor de borracha a 3,5mm de extensão, a polpa foi extirpada, a fim de não 
provocar sintomatologia dolorosa no período pós-operatório ${ }^{12}$. Neste procedimento, somente as raízes distais forma instrumentadas. Os dentes expostos foram deixados abertos na cavidade bucal $16,28,29,31,57,59,62$, com o objetivo de se induzir a contaminação bacteriana e conseqüente lesão periapical inflamatória. O primeiro molar inferior do lado direito foi utilizado como controle negativo interno ${ }^{1,28}$.

\section{3 - Sacrifício dos animais e manipulação dos espécimes}

Os sacrifícios dos animais que sofreram a indução experimental da lesão periapical foram realizados aos 3 (grupo1), 7 (grupo 2), 14 (grupo 3), 21 (grupo 4), 30 (grupo 5), 60 (grupo 6), 90 (grupo 7), 120 (grupo 8) e 180 dias (grupo 9) após a indução da lesão periapical. Animais não submetidos a nenhum tipo de intervenção cirúrgica ou anestesia também foram sacrificados com 45 dias de idade (2 animais) e com 225 dias de idade (2 animais), constituindo o grupo controle totalmente negativo. O sacrifício foi realizado por meio de dose excessiva da solução Dopalen ${ }^{\circledR}$ e Anasedan $®$, misturados na proporção 1:1. Foram sacrificados 5 animais por grupo.

Em seguida, a mandíbula foi removida e separada em duas hemimandíbulas utilizando-se bisturi com lâmina $\mathrm{n}^{0} 15$ Bard-Parker. O material foi colocado em recipientes devidamente etiquetados e fixado em solução de Formol a 10\% tamponado com fosfato, por 48 horas. Em seguida à realização das radiografias periapicais convencionais ${ }^{36}$, as hemimandíbulas foram cortadas em blocos de aproximadamente $8 \times 10 \times 6 \mathrm{~mm}$ (contendo o primeiro molar inferior $)^{50}$ e desmineralizadas em solução de EDTA 7\% por 40 dias, com trocas 
da solução em dias alternados. Após a desmineralização, as amostras foram seccionadas no sentido mesio-distal. Em seguida, de acordo com o protocolo utilizado pelo Laboratório de Patologia do Departamento de Estomatologia da FOB/USP, os espécimes foram processados no aparelho histotécnico Leica TP 1010, incluídos em parafina, e cortados em micrótomo (Leica - modelo RM2165) a 5um. Os cortes forma aderidos em lâminas de vidro comuns para microscopia (Corning ${ }^{\circledR}$ ) já devidamente etiquetadas. Os espécimes foram, então, corados com Hematoxilina-eosina (H.E), protegidos com lamínulas de vidro e as lâminas armazenadas em caixa especial para lâminas para posterior análise em microscopia óptica.

\section{4 - Obtenção e análise das imagens radiográficas}

As hemimandíbulas foram submetidas às tomadas radiográficas, utilizando aparelho radiográfico Dabi-Atlante $70 \mathrm{KVP}$ e películas periapicais com filme KODAK Ultra-speed ${ }^{33}$, a uma distância focal total de $40 \mathrm{~cm}$, aumentada de $20 \mathrm{~cm}$ obtida com tubo de $\mathrm{PVC}^{64}$, o que resulta em um cilindro localizador encaixado no interior do tubo original do aparelho. Desta maneira, foi possível padronizar a direção do feixe de raios $\mathrm{X}$ que incidiam perpendicularmente ao plano de receptor da imagem ${ }^{69}$. O tempo de exposição utilizado foi de 0,5 segundos e o processamento radiográfico realizado manualmente seguiu-se com tempo de revelação de 30 segundos, lavagem em água por 20 segundos, fixação por mínimo 90 segundos e lavagem final em água corrente por 2 minutos, sendo a temperatura da solução reveladora de $22^{\circ} \mathrm{C}$ em média. Os líquidos revelador e fixador utilizados foram da KODAK. 
A seguir, as imagens foram capturadas $^{6}$ utilizando-se um computador com microprocessador Pentiun III, 200 KB de memória RAM, 10 GB de HD, cd-rom 48x, e monitor 17 polegadas, gerenciado pelo sistema operacional Windows 2000, e através do programa Adobe Photoshop 7.0 (Adobe Systems Incorporation, San José) e Scanner de mesa Genius Colorpage - HR7X Slim, com resolução óptica de 1200 pontos por polegada. As radiografias foram organizadas separadamente em arquivos relativos a cada tempo experimental. Em uma sala de aproximadamente $15 \mathrm{~m}^{2}$, com iluminação natural, no período noturno por volta das 20 horas, ou seja, no escuro ${ }^{6}$, cada grupo de radiografias foi digitalizado pelo mesmo pesquisador, com o cuidado de não exceder o tempo de trabalho máximo de duas horas, com intervalos regulares a cada 15 minutos. Utilizando-se o scanner descrito que possui função para radiografias e o programa Adobe, as imagens foram capturadas com resolução de 600 dpi e devidamente identificadas. As imagens digitalizadas foram somente manipuladas no programa Adobe para melhor padronização das imagens (formato JPEG ${ }^{45}$, definição média/alta valor 5), sem quaisquer outros tipos de alterações. Finalizada esta etapa, o programa ImageLab foi utilizado para a medição do perímetro, área e maior diâmetro da lesão periapical induzida.

O Imagelab é um software de análise de imagens que permite o processamento e o cálculo de vários parâmetros em imagens digitalizadas. Tem sido utilizado como ferramenta indispensável de auxílio em pesquisa nas áreas de biologia e engenharia. Os dados das imagens e resultados podem ser armazenados, impressos ou exportados para outros programas, permitindo uma eficiente documentação ${ }^{25}$. Exportando as imagens de um arquivo do 
Adobe, pudemos, com auxílio do ImageLab, calcular os seguintes parâmetros: perímetro, área e o maior diâmetro da lesão periapical, quando presente. Para tanto, em cada imagem utilizamos as ferramentas de calibração da imagem, filtro realce de bordas e remoção de ruído, de acordo com as especificações do fabricante. Então, procedeu-se a medição da lesão periapical visível. Uma vez delimitada a área da rarefação óssea, obtida manualmente com o mouse e colorida para facilitar a visualização, obtivemos os valores calculados automaticamente pelo programa. Organizando estes dados em quadros, a presente análise possibilitou diferentes parâmetros de medição da lesão periapical visível, nos vários períodos de indução experimental.

Os diferentes parâmetros analisados foram:

- cálculo do perímetro: o perímetro de uma estrutura digitalizada corresponde à soma das alturas e larguras dos pixels localizados na periferia da figura. Entretanto, em função do processo de digitalização, o perímetro da estrutura apresenta um aspecto serrilhado que não existe no objeto real. Se o cálculo do perímetro fosse baseado exclusivamente nessa soma (perímetro digitalizado), o resultado poderia ser maior que o valor real. Para corrigir esse processo, pode-se usar como unidade de medida, a distância da reta que corta o pixel ao meio (perímetro interpolado) ${ }^{25}$;

- cálculo de área: a área de uma estrutura digitalizada corresponde à soma dos pixels localizados na periferia e no interior da figura. Entretanto, em função do processo de digitalização, a área da estrutura também apresenta um serrilhado que não existe no objeto real. Se o cálculo da área fosse baseado exclusivamente nessa soma (área digitalizada), o resultado poderia ser maior 
que o valor real. Para corrigir esse processo, pode-se também usar o complemento de medida, ou seja, o triângulo formado pela secção do pixel (área interpolada $^{25}$;

- maior diâmetro: representa a maior distância entre todos os pontos que compõe a periferia de uma estrutura ${ }^{25}$.

A medição de cada parâmetro foi realizada, sempre pelo mesmo operador, por três vezes, com intervalos de aproximadamente um mês. Após a obtenção destas medições, foi calculada a média de cada parâmetro para cada grupo, obtendo-se assim a média de cada medição, totalizando três médias, que então, foram novamente submetidas aos cálculos de média para a obtenção do valor médio final. Por exemplo:

- período experimental de 30 dias (grupo 5): os espécimes (5) apresentaram os seguintes valores em pixels para a área da lesão periapical: 1270.00, 480.50, 1327.61, 1007.00 e 1124.500, onde a soma totalizou 5217.61. Este valor, então, foi dividido por 5 para obtermos a média 1043,52. Este cálculo foi realizado em cada medição, resultando em três médias que foram novamente somadas e divididas por três, resultando assim uma média final (anexo 2,3,4, $5,6,7)$

A partir desta média final para cada período experimental, foi calculado o aumento da lesão de um período para o outro. Este cálculo foi baseado no incremento da lesão. Por exemplo:

- no período experimental de 7 dias (grupo 2), a média final da área da lesão foi de 163.43 pixels, enquanto que no período seguinte (14 dias - grupo 3) este valor foi de 761,27 pixels. Quando calculamos o incremento, que é realizado 
subtraindo o valor 163,43 de 761,27 , obtivemos um valor de 597,8 . Para termos uma visão do que este valor representa, basta transformá-lo em proporção com a regra do teorema de Talles (dividindo 597,8 por 163,43 ), o que resultou assim em um valor de incremento de $365 \%$ ou de 3,65 vezes o tamanho da lesão.

\section{5 - Análise microscópica subjetiva}

As lâminas de vidro contendo as diferentes amostras foram analisadas utilizando-se um microscópio óptico binocular (Olympus $\mathrm{CH}-2$ ), com relação:

\section{- ao infiltrado inflamatório}

- tipo celular predominante: mononucleares (MN) ou polimorfonucleares (PMN);

- localização: região periapical $(P)$ ou região de furca $(F)$;

- distribuição: focal (f) ou difusa(d) e

- intensidade: discreta (D), moderada (M) ou intensa (I).

- às células clásticas

- localização: osso (O), cemento (C), dentina (D);

- intensidade (número de células): discreta (D), moderada (M) ou intensa (I) e

- morfologia: normal (N) ou alterada (A).

\section{- à cavidade cística}

- com epitélio de revestimento e

- sem epitélio de revestimento. 
- aos restos epiteliais de Malassez

- localização: região periapical $(P)$ ou região de furca $(F)$ e

- ao tecido de granulação

- localização: próximo ao ápice ou na periferia da lesão.

A referida análise foi realizada por dois examinadores (denominados A e B) devidamente calibrados e capacitados, sendo os resultados expressos na forma de quadros (anexos 8, 9, 10, 11, 12, 13, 14, 15, 16, 17, 18, 19, 20, 21, $22,23,24,25)$. 
4 - RESULTADOS 


\section{4 - RESULTADOS}

Para melhor padronização da evolução da lesão periapical induzida experimentalmente em ratos, as avaliações restringiram-se às raízes distais, pois somente estas foram instrumentadas no intuito de se retirar a polpa e acelerar a formação da lesão periapical. Esta análise temporal nos permitiu avaliar radiografica e microscopicamente o desenvolvimento e o aumento progressivo da lesão.

\section{1 - Grupos Controle}

Cada período experimental constou de um grupo controle representado pelo $1^{\circ}$ molar inferior do lado direito (controle interno). Em todos os períodos experimentais, estes espécimes apresentaram características de normalidade da região periapical, tanto nos aspectos microscópicos quanto radiográficos.

Adicionalmente, no presente trabalho, foi utilizado um grupo composto de quatro ratos com as mesmas características dos ratos dos grupos de indução da lesão periapical, porém estes não foram submetidos a nenhum tipo de intervenção cirúrgica ou anestesia (grupo controle totalmente negativo). Dois animais foram sacrificados com 45 dias de idade e outros dois, com 225 dias de idade. As análises microscópica e radiográfica apresentaram absoluta normalidade da região periapical, que se encontrava sem qualquer tipo de infiltrado inflamatório, apenas apresentando suas células residentes predominantemente células fusiformes fibroblastos-like, assim como escassos 
restos epiteliais de Malassez e vasos sangüíneos normais (Figura 1). Observaram-se ainda discretas áreas de reabsorção cementária e ou dentinária com a presença de células clásticas em suas lacunas de Howship. Radiograficamente, observaram-se espaço pulpar preservado e radiolucidez regular, continuidade da lâmina dura, espaço periodontal apical regular, normalidade do trabeculado ósseo e ausência de rarefação óssea (Figura 9).

\section{2 - Período experimental de 3 dias (grupo 1)}

Considerando a avaliação microscópica, os dentes avaliados neste período ainda apresentavam polpa radicular viável principalmente no terço apical da raiz estudada, portanto sem sinal de lesão periapical crônica, visto que o ligamento periodontal apical demonstrava-se semelhante ao grupo controle, exceto pela presença de vasos sangüíneos congestos. Observou-se, nestas polpas, infiltrado inflamatório, predominantemente polimorfonuclear, localizado tanto na região periapical (Figura 2) quanto de furca, de distribuição difusa e intensidade variando de discreta a moderada, compatível com pericementite apical aguda. Escassas células clásticas estavam presentes na superfície óssea ao redor do ápice, com morfologia e número de núcleos normais (de 1 a $5)$.

Radiograficamente, observou-se discreto espessamento do ligamento periodontal (Figura 10), sugestivo de pericementite apical aguda, sem características de rarefação óssea. Portanto, os aspectos radiográficos foram concordantes com os microscópicos. 


\section{3 - Período experimental de 7 dias (grupo 2)}

No período de 7 dias, a análise microscópica das polpas das raízes avaliadas (distais) revelava necrose e moderado infiltrado inflamatório polimorfonuclear nas regiões apical (Figura 3) e de furca, caracterizando uma lesão periapical, compatível com pericementite apical aguda. As células clásticas foram notadas nas superfícies ósseas e cementária apical. Em somente um dos espécimes, foi observada a presença de cavidade cística, porém sem epitélio de revestimento. Quanto aos restos epiteliais de Malassez, estes foram observados em pequeno número na região de furca. Notaram-se ainda, próximo ao ápice e na periferia da lesão apical, um grande número de vasos sangüíneos congestos compatível com tecido de granulação.

Quanto aos aspectos radiográficos, observou-se pequena rarefação óssea localizada no ápice da raiz distal (Figura 11). As medidas médias observadas através do programa Image Lab foram as seguintes: valores relativos da área = 761,27 , do perímetro $=151,53$ e d o diâmetro $=46,92($ anexo $2-$ quadro 4$)$.

\section{4 - Período experimental de 14 dias (grupo 3)}

Os cortes microscópicos revelaram principalmente moderado infiltrado inflamatório polimorfonuclear difusamente distribuído nas regiões periapical distal e de furca, caracterizando lesão periapical aguda. Alguns cortes microscópicos demonstraram na região periapical, a presença de tecido de granulação (figura 4). Nas superfícies óssea e cementária, notou-se a presença de células clásticas de morfologia normal. A presença de cavidade cística foi notada em todos os espécimes deste grupo, algumas com epitélio de 
revestimento (Figura 5). Os restos epiteliais de Malassez foram vistos mais freqüentemente na região periapical, enquanto os vasos sangüíneos congestos foram observados na periferia da lesão apical Radiograficamente, observou-se um nítido aumento da lesão radiolúcida situada na raiz distal, apresentando-se como rarefação óssea bem definida, delimitada por uma fina linha radiopaca contínua, de contorno arredondado (Figura 12). A área da lesão medida através do programa ImageLab teve um incremento de 3,65 vezes (365\%) em relação ao período anterior. O perímetro e o diâmetro da lesão tiveram um incremento respectivamente de 1,49 vezes (149\%) e de 1,48 vezes (148\%) em relação ao período experimental anterior, caracterizando um grande crescimento da lesão (anexo 3 - quadro 8 ).

\section{5 - Período experimental de 21 dias (grupo 4)}

Microscopicamente, na região periapical distal, verificou-se que o infiltrado inflamatório era moderado e do tipo polimorfonuclear, porém de distribuição focal na maioria dos espécimes, e localizado tanto na região do periápice quanto de furca. O número e a morfologia das células clásticas eram semelhantes comparados com o período anterior. A presença de cavidade cística foi notada em somente dois espécimes e os restos epiteliais de Malassez foram vistos mais freqüentemente na região de furca. Tecido de granulação foi observado na periferia da lesão apical. Os achados microscópicos sugerem, então, o surgimento de uma lesão apical mais estabelecida, comparando-se com o grupo anterior. 
Na avaliação radiográfica, pôde-se observar as mesmas características do grupo anterior, como rarefação óssea bem definida, delimitada por uma fina linha radiopaca contínua, de contorno arredondado, porém sem aumento de tamanho significativo da lesão (Figura 13). Os parâmetros medidos através do Image Lab nos permite dizer que houve, em relação ao período anterior, um incremento na área e perímetro da lesão de 0,07 vezes (7\%), e o diâmetro da lesão teve uma diminuição de também 0,07 vezes (7\%) (anexo 4 - quadro 12).

\section{6 - Período experimental de 30 dias (grupo 5)}

Neste período experimental, na região periapical distal, microscopicamente o infiltrado inflamatório polimorfonuclear era difuso, ora moderado ora intenso, localizado tanto na região periapical quanto de furca. Nas superfícies óssea e cementária apical, bem como dentinária, em alguns espécimes, observaram-se inúmeras células clásticas. Em todos os espécimes, foram encontradas cavidades císticas com epitélio de revestimento na região periapical, bem como restos epiteliais de Malassez na região de periápice e de furca. Na periferia da lesão apical e próximo ao ápice radicular, notou-se a presença de tecido de granulação.

Radiograficamente, observou-se pouca mudança em relação aos dois últimos períodos analisados, ou seja, rarefação óssea bem definida, delimitada por uma fina linha radiopaca contínua, de contorno arredondado, porém com pequeno aumento de tamanho da lesão na raiz distal. Além disso, notou-se a presença de lesão radiolúcida, com as mesmas características descritas, nas outras raízes dos dentes analisados (Figura 14). Quanto aos parâmetros 
analisados, observamos que houve um incremento na área da lesão em relação ao período anterior de 0,17 vezes (17\%), e de 0,10 vezes (10\%) para o perímetro e para o maior diâmetro (anexo 5 - quadro 16).

\section{7 - Período experimental de 60 dias (grupo 6)}

Quanto aos achados microscópicos deste período, observou-se, na região periapical distal, em alguns espécimes, o predomínio de infiltrado inflamatório mononuclear, caracterizando a cronicidade do processo inflamatório, enquanto em outros o predomínio de infiltrado inflamatório polimorfonuclear. Quanto às demais características microscópicas, não se observaram alterações relevantes quando comparadas com o período anterior (figura 6).

Quanto aos aspectos radiográficos, não se observaram alterações significantes em comparação ao período anterior (Figura 15), mesmo em relação aos parâmetros mensurados que apresentaram os seguintes incrementos em relação ao período experimental de 30 dias: aumento de 0,07 vezes (7\%) para a área da lesão; 0,009 vezes (0,9\%) para o perímetro e 0,11 vezes (11\%) para o maior diâmetro (anexo 6 - quadro 20).

\section{8 - Período experimental de 90 dias (grupo 7)}

Aos 90 dias após a indução experimental da lesão periapical, a análise microscópica revelou alterações especialmente quanto ao infiltrado inflamatório, que se tornou predominantemente mononuclear, de intensidade moderada a intensa, distribuído difusamente e localizado tanto na região periapical com de furca. Quanto às células clásticas, verificou-se sua presença 
nas superfícies óssea, cementária e dentinária. Também neste período, observou-se a presença de cavidade cística na maioria dos espécimes, e com epitélio de revestimento. Os restos epiteliais de Malassez foram vistos predominantemente na região de furca. Tecido de granulação estava presente na periferia da lesão periapical (figura 7).

Os aspectos radiográficos foram semelhantes àqueles observados no período anterior, exceto em alguns espécimes, nos quais se verificou maior delimitação da rarefação óssea, compatível com lesão periapical crônica (Figura 16). Os valores medidos pelo programa ImageLab relacionados à área da lesão revelaram um aumento de 0,03 vezes (3\%) e 0,01 vez (1\%) para o perímetro e para o maior diâmetro da lesão, respectivamente (anexo 7 - quadro 24).

\section{9 - Período experimental de 120 dias (grupo 8)}

Neste período experimental, observou-se a fratura coronária em alguns espécimes, dificultando a análise tanto microscópica como radiográfica. Microscopicamente, notou-se que o infiltrado inflamatório na região periapical distal permaneceu predominantemente mononuclear difuso, variando de moderado a intenso, localizado tanto na região de furca como periapical. Todos os espécimes apresentaram cavidade cística (figura 8). Os restos epiteliais de Malassez foram visualizados em alguns espécimes nas regiões de furca e periapical, assim como as células clásticas nas superfícies ósseas, cementária e dentinária e o tecido de granulação na periferia da lesão apical. 
Em relação aos achados radiográficos, observou-se que, nos espécimes onde ocorreu a fratura coronária, a lesão radiolúcida tornou-se mais extensa, unindose com as lesões presentes nas outras raízes (Figura 17). A medição através do programa Imagelab tornou-se inviável.

\subsection{0 - Período experimental de 180 dias (grupo 9)}

Neste período, não foram observadas alterações importantes em relação ao grupo anterior, tanto quanto aos aspectos microscópicos quanto radiográficos. Radiograficamente, notou-se também fratura coronária em quase todos os espécimes, dificultando a análise da lesão apical, e freqüentemente inviabilizando sua medição, já que esta se fundiu com a lesão apical das outras raízes (Figura 18).

Alguns espécimes foram perdidos durante o processamento, sendo que nos referidos quadros em anexo, aparecem como espaços não preenchidos. 

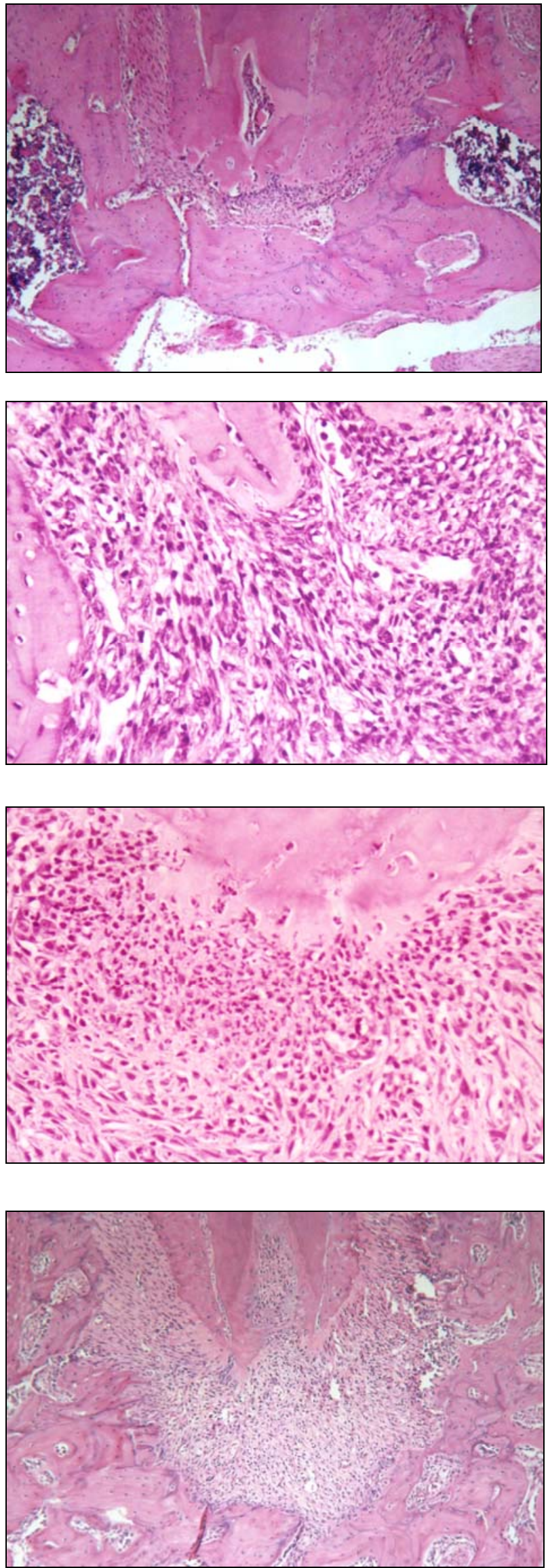

Figura 1 - Fotomicrografia do $1^{0}$ molar inferior de um animal com 45 dias de idade representando o grupo controle totalmente negativo. Observa-se normalidade da região periapical, com células fusiformes fibroblastos-like e ausência de infiltrado inflamatório (aumento original $\cong 25 x$ ).

Figura 2 - Fotomicrografia da região periapical do $1^{\circ}$ molar inferior esquerdo, no período experimental de 3 dias após a indução (grupo 1). Observa-se infiltrado inflamatório com predomínio de células polimorfonucleares (aumento original $\cong 100 x$ ).

Figura 3 - Fotomicrografia da região periapical do $1^{\circ}$ molar inferior esquerdo, no período experimental de 7 dias após a indução (grupo 2). Observa-se infiltrado inflamatório polimorfonuclear e presença de fibroblastos na periferia da lesão (aumento original $\cong 100 x$ ).

Figura 4 - Fotomicrografia da região periapical do $1^{\circ}$ molar inferior esquerdo, no período experimental de 14 dias após a indução (grupo 3). Observa-se na região periapical a presença de tecido de granulação (aumento original $\cong 25 x$ ). 

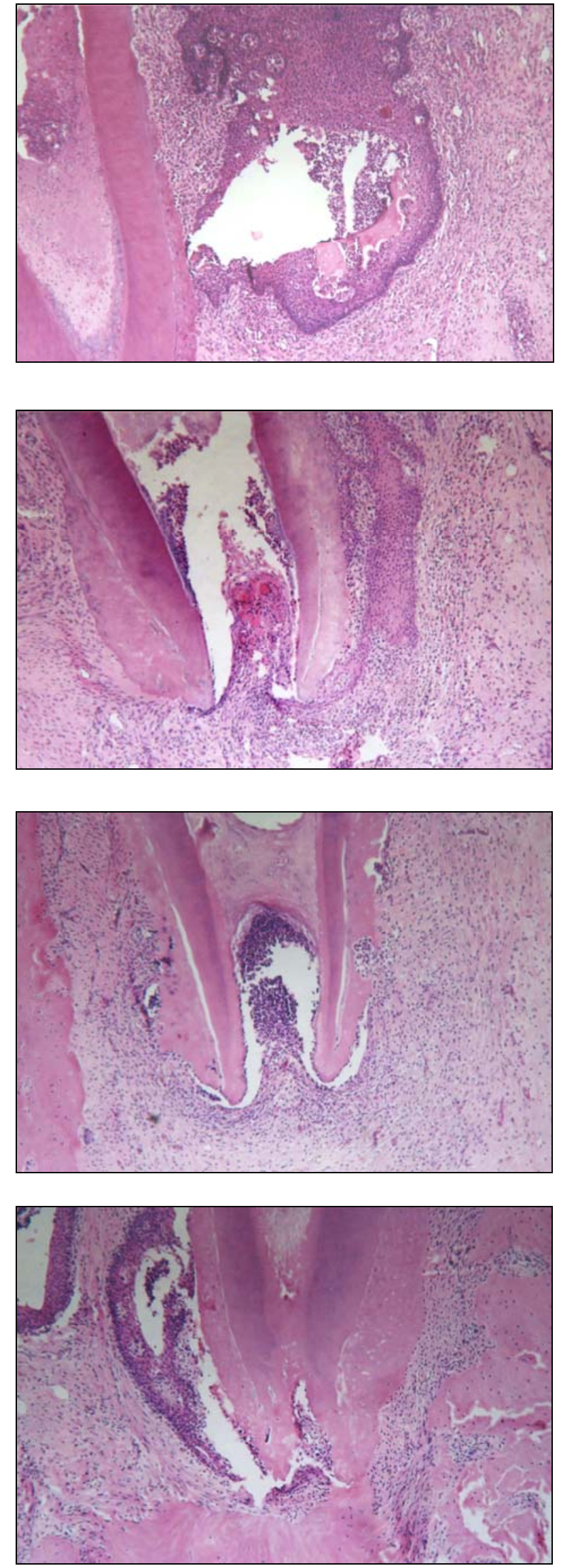

Figura 5 - Fotomicrografia da região periapical do $1^{\circ}$ molar inferior esquerdo, no período experimental de 14 dias após a indução (grupo 3). Observa-se moderado infiltrado inflamatório polimorfonuclear e presença de cavidade cística com epitélio de revestimento (aumento original $\cong 25 x$ ).

Figura 6 - Fotomicrografia da região periapical do $1^{\circ}$ molar inferior esquerdo, no período experimental de 60 dias após a indução (grupo 6). Observa-se necrose pulpar e na região periapical a presença de infiltrado inflamatório e proliferação epitelial; sugestivo de revestimento epitelial cístico (aumento original $\cong 25 x$ ).

Figura 7 - Fotomicrografia da região periapical do $1^{\circ}$ molar inferior esquerdo, no período experimental de 90 dias após a indução (grupo 7). Observa-se no terço apical intenso infiltrado inflamatório e a região periapical a presença de tecido de granulação maduro. A superfície radicular apresenta áreas de reabsorção (aumento original $\cong 25 x$ ).

Figura 8 - Fotomicrografia da região periapical do $1^{\circ}$ molar inferior esquerdo, no período experimental de 120 dias após a indução (grupo 8). Observa-se infiltrado inflamatório na região periapical e mais lateralmente, cavidade cística (aumento original $\cong$ $25 x)$. 

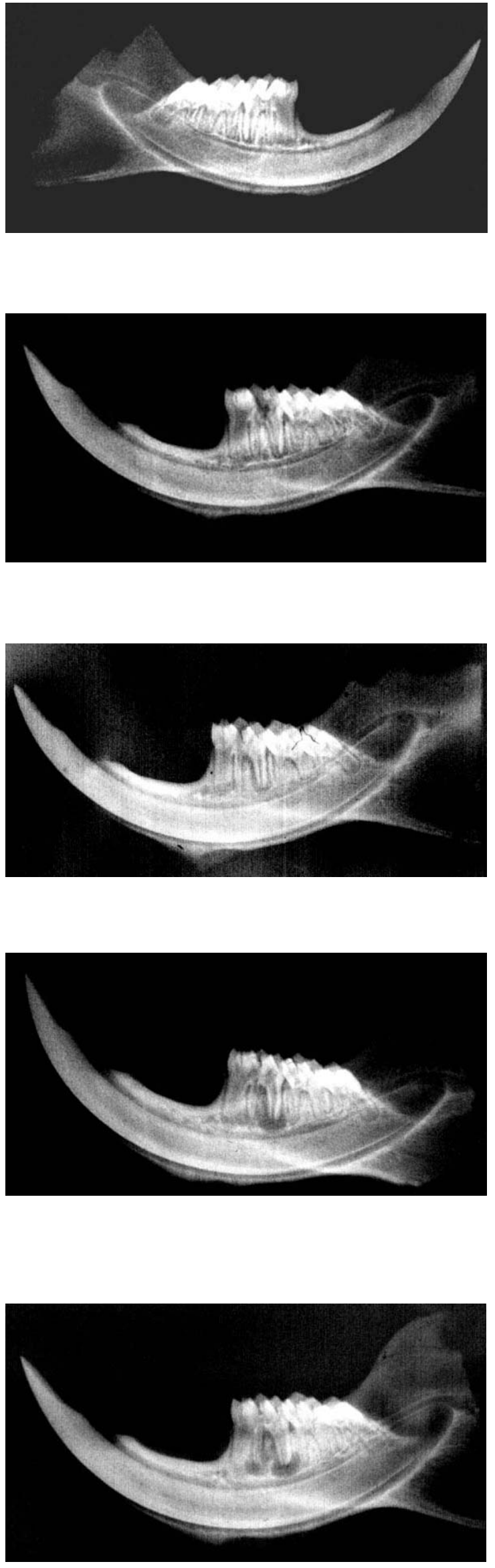

Figura 9 - Radiografia da hemimandíbula direita, representando o grupo controle totalmente negativo. Observa-se lâmina dura íntegra, normalidade do trabeculado ósseo e ausência de rarefação óssea na raiz distal do $1^{\circ}$ molar inferior.

Figura 10 - Radiografia da hemimandíbula esquerda, no período experimental de 3 dias após a indução (grupo 1). Observa-se pequeno espessamento do ligamento periodontal na raiz distal do $1^{\circ}$ molar inferior.

Figura 11 - Radiografia da hemimandíbula esquerda, no período experimental de 7 dias após a indução (grupo 2). Observa-se rarefação óssea na raiz distal do $1^{\circ}$ molar inferior.

Figura 12 - Radiografia da hemimandíbula esquerda, no período experimental de 14 dias após a indução (grupo 3). Observa-se lesão radiolúcida na raiz distal do $1^{\circ}$ molar inferior, apresentando-se como rarefação óssea bem definida, delimitada por uma fina linha radiopaca contínua, de contorno arredondado.

Figura 13 - Radiografia da hemimandíbula esquerda, no período experimental de 21 dias após a indução (grupo 4). Observa-se na raiz distal do $1^{\circ}$ molar inferior, rarefação óssea bem definida, delimitada por linha radiopaca contínua, de contorno arredondado. 

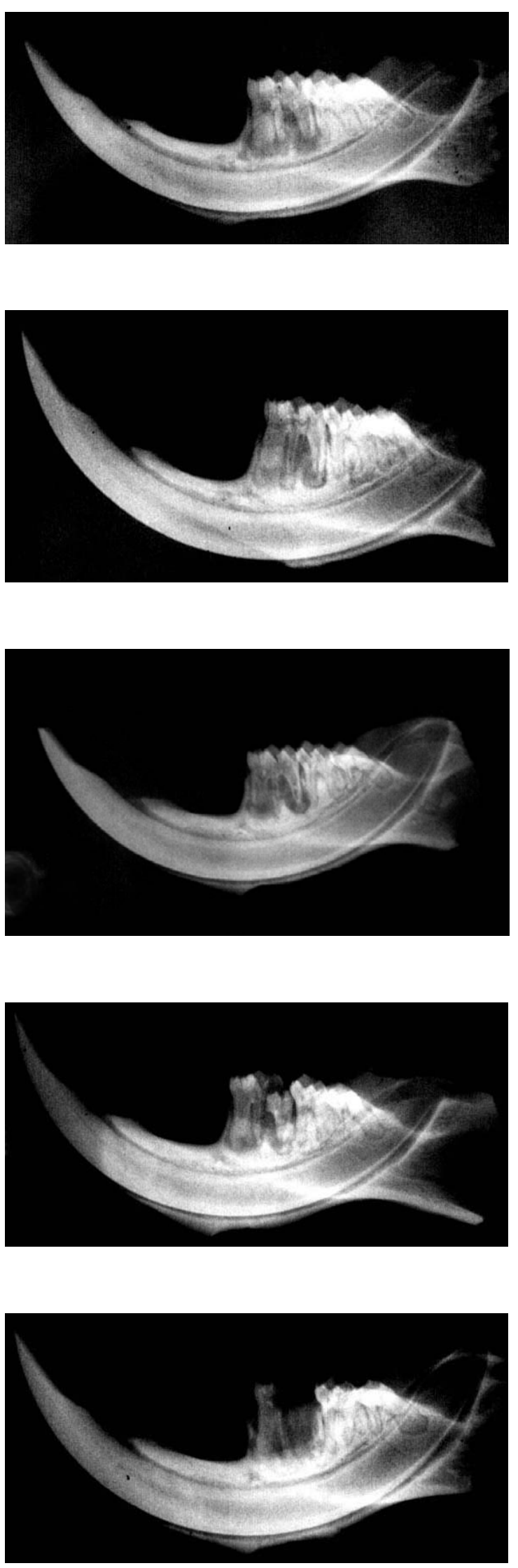

Figura 14 - Radiografia da hemimandíbula esquerda, no período experimental de 30 dias após a indução (grupo 5). Observa-se na raiz distal do $1^{\circ}$ molar inferior, rarefação óssea bem definida, assim como nas demais raízes.

Figura 15 - Radiografia da hemimandíbula esquerda, no período experimental de 60 dias após a indução (grupo 6). Observa-se nas raízes do $1^{\circ}$ molar inferior, rarefação óssea bem definida, delimitada por linha radiopaca contínua.

Figura 16 - Radiografia da hemimandíbula esquerda, no período experimental de 90 dias após a indução (grupo 7). Observa-se nas raízes do $1^{\circ}$ molar inferior, extensa rarefação óssea.

Figura 17 - Radiografia da hemimandíbula esquerda, no período experimental de 120 dias após a indução (grupo 8). Observa-se fratura radicular e extensa rarefação óssea atingindo todas as raízes do dente.

Figura 18 - Radiografia da hemimandíbula esquerda, no período experimental de 180 dias após a indução (grupo 9). Observa-se fratura radicular e rarefação óssea atingindo todas as raízes do dente. 
5 - DISCUSSÃO 


\section{5 - DISCUSSÃO}

O rato é utilizado freqüentemente como modelo experimental ${ }^{23,58} \mathrm{em}$ pesquisas científicas. No presente estudo, optamos por utilizá-los pela facilidade de obtenção ${ }^{16}$ e de manutenção, além do baixo custo da sua utilização, quando comparado com cães, gatos ou ainda macacos ${ }^{16}$. Os ratos de laboratório são animais isogênicos, possibilitando também maior credibilidade aos resultados ${ }^{16}$. Em nosso trabalho, foram utilizados ratos com 45 dias de idade ${ }^{56}$, por representarem adultos jovens, sendo que estes animais atingem a maturidade sexual em torno do $30^{\circ}$ ao $50^{\circ}$ dia de idade ${ }^{47,53,56}$. O primeiro molar inferior, mais especificamente seu canal radicular distal, foi eleito para a indução da lesão periapical pela facilidade de acesso endodôntico e radiográfico ${ }^{12}$, bem como pela anatomia semelhante à humana ${ }^{16}$.

A exposição pulpar realizada pelo método descrito no presente trabalho foi preconizada por KAKEHASHI, STANLEY e FITZGERALD ${ }^{28}$ e seguida por diversos autores ${ }^{10,12,16,29,31,57,59,62}$, entre eles EURASQUIN e MURUZÁBAL ${ }^{16}$ (1967), que ainda propuseram um protocolo de estudo de terapia endodôntica em canais radiculares de dentes de ratos submetidos a esta condição.

A reação periapical provocada pela exposição pulpar segue, no rato, a mesma evolução que no homem, ou seja, formação de periapicopatia inflamatória. A utilização do modelo de doença periapical induzida experimentalmente, em ratos, possibilita o estudo da dinâmica da evolução destas lesões ${ }^{10,57,59}$. Assim, as análises microscópica e radiográfica da lesão periapical induzida permitiram 
um estudo aprimorado de seus vários períodos de desenvolvimento, possibilitando identificar o que ocorre em cada fase, o que pode colaborar para o estudo de futuras investigações utilizando este modelo experimental.

Nas diferentes fases do desenvolvimento da lesão periapical, neste estudo, foi possível identificar os tipos celulares presentes, constatando o predomínio de polimorfonucleares até o período de 90 dias após a indução experimental. Visto que células clásticas já eram observadas nas superfícies ósseas desde o período de 3 dias, e óssea e dentária desde o período de 7 dias, períodos estes nos quais não se observaram ainda células mononucleares, é possível que a atividade mediada pelos polimorfonucleares possa estar envolvida na destruição óssea em lesões periapicais induzidas em ratos ${ }^{59}$. Entretanto, nossos resultados diferem de outros trabalhos ${ }^{31}$, nos quais as lesões periapicais induzidas em molares de ratos apresentavam predomínio de macrófagos em todos os períodos experimentais.

A partir de nossos resultados, pudemos observar que as lesões periapicais induzidas experimentalmente em ratos desenvolveram-se rapidamente entre 7 e 14 dias após a sua indução, expandindo consideravelmente e apresentando reabsorção óssea progressiva nestes períodos. Entretanto, nos períodos correspondentes aos 21, 30 e 60 dias após a indução, a expansão e a reabsorção ósseas evoluíram mais lentamente, ocorrendo relativa estabilização da lesão periapical entre os 60 e 90 dias após a indução da doença. Nossos achados são concordantes com os de outros autores ${ }^{10,57,58,73}$, que estabeleceram os períodos iniciais de indução, entre os dias 0 e 15, como fase ativa, quando há crescimento contínuo da lesão e grande atividade de 
reabsorção óssea ${ }^{57}$; já nos períodos subseqüentes, o crescimento foi mais lento, estabilizando-se após 90 dias de indução, caracterizando a fase crônica ${ }^{58}$.

A identificação da presença do cisto periodontal apical neste trabalho foi possível a partir do $14^{\circ}$ dia após a indução da lesão periapical, ocorrendo em todos os espécimes aos 30, 60, 90 e 120 dias após a indução experimental, inclusive com evidência de epitélio de revestimento. Enquanto, era esperada a formação de granuloma periapical como conseqüência da reação periapical pela exposição pulpar ao meio bucal em ratos ${ }^{16}$.

A maioria dos estudos presentes na literatura $12,16,28,29,31,57,59,62$ apresentam períodos experimentais mais curtos quando comparados com o presente trabalho, que objetivou caracterizar a evolução microscópica e radiográfica das lesões periapicais induzidas experimentalmente, estabelecendo os períodos mais significantes. No entanto, nos períodos finais de nosso estudo, aos 120 e 180 dias após a indução da doença, a ocorrência de fratura coronária no primeiro molar inferior esquerdo, na maioria dos espécimes, prejudicou a avaliação devido à formação de lesão perirradicular ou, ainda, da união das lesões periapicais de todas as raízes. Sendo assim, a não inclusão de períodos mais tardios no estudo da lesão periapical experimentalmente induzida em ratos pode ser justificada a partir dos dados obtidos no presente trabalho.

Radiograficamente, em nosso estudo, as lesões periapicais induzidas em ratos apresentaram, a partir do período experimental relativo aos 7 dias após a indução, áreas radiolúcidas, expandindo-se progressivamente até os 14 dias. Aos 21,30 e 60 dias de indução, a progressão da lesão periapical foi mais 
lenta, sendo que nos períodos de 60 e 90 dias ocorreu a estabilização da lesão. Alguns autores descrevem a presença de áreas radiolúcidas compatíveis com lesão periapical a partir do $5^{\circ}$ dia após sua indução experimental em ratos, notando ainda o aumento significativo da lesão num período de 5 a 20 dias $^{36}$. No presente estudo, optamos por realizar radiografias convencionais submetidas posteriormente à digitalização para análise radiográfica. Esta opção provém do fato da radiografia convencional ser um método conhecido, de baixo custo, controlável, acessível e facilmente exeqüível ${ }^{6,7,18,22}$. Para se obter a melhor qualidade possível das radiografias, foram utilizados filmes KODAK Ultra-speed, que apresentam como vantagens um ótimo contraste, boa qualidade de imagem e alta satisfação ${ }^{33}$, desde que seguidas as recomendações do fabricante. Trabalhos prévios afirmam que o filme Ektaspeed possui maior granulação e menor definição de imagem quando comparado com o Ultra-speed ${ }^{19}$, porém sem diferença estatística significativa ${ }^{24}$. No entanto, muitos autores ${ }^{33,64}$ consideram o filme Ultra-speed superior ao Ekta-speed em termos de contraste, qualidade de imagem e alta satisfação ${ }^{33}$ utilizando então o filme Ultra-speed principalmente em trabalhos científicos ${ }^{64}$. Grande importância tem sido dada à diminuição da dose de radiação para o paciente, fator considerado durante a indicação clínica de tomadas radiográficas. Desde então, muitos estudos têm comparado as vantagens e desvantagens da utilização de métodos digitais de obtenção da imagem, que necessitam de menor quantidade de radiação, com relação aos métodos convencionais. No entanto, a grande maioria dos estudos demonstra não haver diferença estatisticamente significativa quando se compara o método 
convencional com a radiografia digital, quanto à eficácia da interpretação radiográfica ${ }^{32,40,60,70,72}$. Em nosso trabalho, utilizamos um método adicional de análise da imagem radiográfica, e pudemos observar que a digitalização da imagem obtida de maneira convencional, quando comparada àquela obtida diretamente da película radiográfica, apresentou vantagens quanto à interpretação da imagem. A possibilidade de manipulação da imagem, especialmente com relação às funções de brilho e contraste, torna este método um intermediário entre a radiografia digital e a convencional. Além disso, radiografias scaneadas e gravadas em arquivos em formato JPEG ${ }^{25}$, possibilitam o armazenamento da imagem intacta, sem problemas futuros de desaparecimento da imagem, o que geralmente ocorre quando as radiografias obtidas pelo método convencional não são adequadamente processadas.

No presente trabalho, realizando uma correlação entre os achados microscópicos e radiográficos, podemos afirmar, ainda, que a maioria das alterações microscópicas, como presença de lesão periapical, reabsorções óssea e dentinária, assim como a presença de fratura coronária também foi identificada radiograficamente. Adicionalmente, os aspectos radiográficos corroboram os aspectos microscópicos, indicando lesão periapical incipiente compatível com pericementite apical aguda aos 3 dias, e lesão periapical crônica, muitas vezes com cavidade cística, a partir do $14^{\circ}$ dia, a qual demonstrava rarefação óssea bem definida delimitada por uma fina linha radiopaca contínua. Estes aspectos radiográficos são semelhantes àqueles relacionados com a lesão periapical inflamatória em humanos. Por outro lado, quando a lesão periapical se estabelecia a partir do $7^{\circ}$ ao $14^{\circ}$ dia após a 
indução experimental, o infiltrado inflamatório era predominantemente polimorfonuclear, tornando-se mononuclear predominantemente apenas aos 60 dias. Como já mencionado, é possível que, em lesões periapicais induzidas em ratos, os polimorfonucleares tenham uma importante participação nos fenômenos que envolvem a ativação dos osteoclastos, enquanto que as células mononucleares estejam associadas com a estabilização da doença apical inflamatória, ao menos neste modelo experimental.

Considerando as limitações de todo modelo experimental e as peculiaridades do modelo utilizado no presente trabalho, consideramos o rato um excelente modelo experimental para o estudo da lesão periapical inflamatória. 


\section{6 - CONCLUSÕES}




\section{6 - CONCLUSÕES}

A partir da análise radiográfica e microscópica dos resultados obtidos por meio deste modelo experimental, pode-se concluir que:

- a partir do primeiro período avaliado (3 dias), os aspectos radiográficos foram concordantes com os microscópicos,

- a presença do aspecto microscópico - cavidade cística - e do aspecto radiográfico - rarefação óssea localizada - na região apical da raiz distal do primeiro molar inferior esquerdo foi observada a partir do período de 7 dias após a indução,

- as lesões periapicais aumentaram nitidamente entre os períodos experimentais de 3 e 14 dias após a indução, expandindo em menor proporção nos períodos de 14 a 60 dias e se estabilizaram aos 60 e 120 dias,

- a fase ativa de evolução da lesão apical, com importante destruição óssea, relacionou-se com a predominância de um infiltrado inflamatório polimorfonuclear, enquanto que o infiltrado apresentava-se predominantemente mononuclear na fase de estabilização da lesão induzida,

- os aspectos radiográficos referentes à lesão induzida em ratos apresentam-se semelhantes àqueles da doença periapical inflamatória em humanos, assim, o modelo animal utilizado mostrou-se satisfatório para o estudo da evolução de lesões periapicais inflamatórias. 
ANEXOS 


\title{
Anexo 1
}

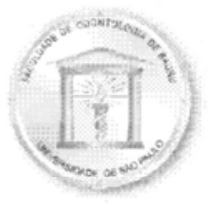

\author{
Universidade de São Paulo \\ Faculdade de Odontologia de Bauru \\ Al. Dr. Octávio Pinheiro Brisolla, 9-75 - Bauru-SP - CEP 17012-901 - C.P. 73 \\ PABX (0XX14)235-8000 - FAX (0XX14)223-4679 \\ Comissão de Ética no Ensino e Pesquisa em Animais
}

CEEPA-Proc. $N^{\circ} 026 / 2003$

Bauru, 02 de outubro de 2003

Senhora Professora,

O projeto de pesquisa encaminhado a esta Comissão de Ética no Ensino e Pesquisa em Animais, denominado "Estudo radiográfico e microscópico de lesões periapicais induzidas em ratos." de autoria de Lidiane de Castro Pinto, que será desenvolvido sob sua orientação foi encaminhado ao Relator para apreciação e considerado aprovado com recomendação em reunião realizada no dia 03 de setembro de 2003 .

Após o envio das informações solicitadas, esta Comissão APROVOU o referido projeto de pesquisa.

Solicitamos que após o término do trabalho, seja encaminhado relatório das atividades desenvolvidas, para parecer final desta Comissão que servirá para publicação do trabalho de pesquisa.

Atenciosamente,

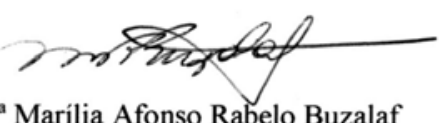

Prof Dra Marilia Afonso Rabelo Buzalaf

Presidente da Comissão de Ética no Ensino e Pesquisa em Animais

Ilm $^{\mathrm{a}} \mathrm{Sr}^{\mathrm{a}} \mathrm{Prof}^{\mathrm{a}} \mathrm{Dr}^{\mathrm{a}}$ Vanessa Soares Lara

DD. Docente do Departamento de Estomatologia (Patologia) 


\section{Anexo 2}

Quadro 1 - Valores relativos à $1^{a}$ medição dos parâmetros: área, perímetro e diâmetro maior, calculados através do programa ImageLab, de cada espécime*, no período de 7 dias (grupo 2).

\begin{tabular}{|c|c|c|c|c|}
\hline espécime & 1 & 2 & \multicolumn{1}{c|}{3} & \multicolumn{1}{c|}{ média } \\
\hline área & 229.00 & 96.50 & 163.00 & 162.83 \\
\hline perímetro & 72.62 & 47.55 & 60.97 & 60.38 \\
\hline diâmetro maior & 19.00 & 18.00 & 18.00 & 18.33 \\
\hline
\end{tabular}

Quadro 2 - Valores relativos à $2^{\mathrm{a}}$ medição dos parâmetros: área, perímetro e diâmetro maior, calculados através do programa ImageLab, de cada espécime*, no período de 7 dias (grupo 2).

\begin{tabular}{|c|l|l|l|l|}
\hline espécime & \multicolumn{1}{|c|}{1} & \multicolumn{1}{c|}{2} & \multicolumn{1}{c|}{3} & \multicolumn{1}{c|}{ média } \\
\hline área & 208.00 & 137.00 & 148.00 & 164.33 \\
\hline perímetro & 57.65 & 59.79 & 60.97 & 59.47 \\
\hline diâmetro maior & 16.00 & 19.41 & 20.00 & 18.47 \\
\hline
\end{tabular}

Quadro 3 - Valores relativos à $3^{\mathrm{a}}$ medição dos parâmetros: área, perímetro e diâmetro maior, calculados através do programa Image Lab, de cada espécime*, no período de 7 dias (grupo 2).

\begin{tabular}{|c|l|l|l|l|}
\hline espécime & 1 & \multicolumn{1}{|c|}{2} & \multicolumn{1}{c|}{3} & média \\
\hline área & 115.21 & 232.00 & 142.61 & 163.27 \\
\hline perímetro & 53.28 & 73.79 & 60.56 & 62.56 \\
\hline diâmetro maior & 17.00 & 22.36 & 20.00 & 19.78 \\
\hline
\end{tabular}

Quadro 4 - Valores relativos à média final dos parâmetros: área, perímetro e diâmetro maior, calculados através do programa ImageLab, de cada medição, no período de 7 dias (grupo 2).

\begin{tabular}{|c|l|}
\hline área & 163.47 \\
\hline perímetro & 60.80 \\
\hline diâmetro maior & 18.86 \\
\hline
\end{tabular}




\section{Anexo 3}

Quadro 5- Valores relativos à $1^{\text {a }}$ medição dos parâmetros: área, perímetro e diâmetro maior, calculados através do programa ImageLab, de cada espécime, no período de 14 dias (grupo 3).

\begin{tabular}{|c|l|l|l|l|l|l|}
\hline espécime & \multicolumn{1}{c|}{1} & \multicolumn{1}{c|}{2} & \multicolumn{1}{c|}{3} & \multicolumn{1}{c|}{4} & \multicolumn{1}{c|}{5} & \multicolumn{1}{c|}{ média } \\
\hline área & 528.00 & 555.00 & 245.00 & 962.00 & 1278.00 & 713.60 \\
\hline perímetro & 122.76 & 117.45 & 97.79 & 179.05 & 203.39 & 144.09 \\
\hline diâmetro maior & 28.00 & 31.00 & 22.00 & 56.93 & 58.00 & 39.18 \\
\hline
\end{tabular}

Quadro 6- Valores relativos à $2^{\mathrm{a}}$ medição dos parâmetros: área, perímetro e diâmetro maior, calculados através do programa ImageLab, de cada espécime, no período de 14 dias (grupo 3).

\begin{tabular}{|c|l|l|l|l|l|l|}
\hline espécime & \multicolumn{1}{c|}{1} & \multicolumn{1}{c|}{2} & \multicolumn{1}{c|}{3} & \multicolumn{1}{c|}{4} & \multicolumn{1}{c|}{5} & \multicolumn{1}{c|}{ média } \\
\hline área & 995.61 & 557.50 & 708.00 & 943.23 & 780.61 & 796.99 \\
\hline perímetro & 188.51 & 140.52 & 173.74 & 173.13 & 156.16 & 166.41 \\
\hline diâmetro maior & 57.00 & 34.00 & 59.00 & 50.00 & 37.00 & 47.40 \\
\hline
\end{tabular}

Quadro 7- Valores relativos à $1^{\text {a }}$ medição dos parâmetros: área, perímetro e diâmetro maior, calculados através do programa ImageLab, de cada espécime, no período de 14 dias (grupo 3).

\begin{tabular}{|c|c|c|l|l|l|l|}
\hline espécime & \multicolumn{1}{c|}{1} & \multicolumn{1}{c|}{2} & \multicolumn{1}{c|}{3} & \multicolumn{1}{c|}{4} & \multicolumn{1}{c|}{5} & média \\
\hline área & 774.50 & 679.00 & 573.00 & 1093.50 & 747.61 & 773.23 \\
\hline perímetro & 171.84 & 174.42 & 173.25 & 183.15 & 172.85 & 144.10 \\
\hline diâmetro maior & 50.00 & 56.00 & 56.00 & 57.00 & 52.00 & 54.20 \\
\hline
\end{tabular}

Quadro 8- Valores relativos à média final dos parâmetros: área, perímetro e diâmetro maior, calculados através do programa ImageLab, de cada medição, no período de 14 dias (grupo 3).

\begin{tabular}{|c|l|}
\hline área & 761.27 \\
\hline perímetro & 151.53 \\
\hline diâmetro maior & 46.92 \\
\hline
\end{tabular}




\section{Anexo 4}

Quadro 9 - Valores relativos à $1^{\text {a }}$ medição dos parâmetros: área, perímetro e diâmetro maior, calculados através do programa ImageLab, de cada espécime, no período de 21 dias (grupo 4).

\begin{tabular}{|c|l|l|l|l|l|l|}
\hline espécime & \multicolumn{1}{c|}{1} & \multicolumn{1}{c|}{2} & \multicolumn{1}{c|}{3} & \multicolumn{1}{c|}{4} & \multicolumn{1}{c|}{5} & \multicolumn{1}{c|}{ média } \\
\hline área & 804.23 & 631.00 & 491.50 & 885.61 & 1122.50 & 786.96 \\
\hline perímetro & 186.31 & 148.76 & 147.01 & 174.65 & 191.49 & 169.64 \\
\hline diâmetro maior & 52.00 & 38.00 & 44.00 & 49.00 & 59.00 & 48.40 \\
\hline
\end{tabular}

Quadro 10 - Valores relativos à $2^{\mathrm{a}}$ medição dos parâmetros: área, perímetro e diâmetro maior, calculados através do programa ImageLab, de cada espécime, no período de 21 dias (grupo 4).

\begin{tabular}{|c|l|l|l|l|l|l|}
\hline espécime & \multicolumn{1}{c|}{1} & \multicolumn{1}{c|}{2} & \multicolumn{1}{c|}{3} & \multicolumn{1}{c|}{4} & \multicolumn{1}{c|}{5} & \multicolumn{1}{c|}{ média } \\
\hline área & 654.00 & 616.11 & 609.50 & 994.61 & 833.00 & 741.44 \\
\hline perímetro & 128.42 & 119.43 & 123.01 & 171.19 & 151.74 & 138.76 \\
\hline diâmetro maior & 33.00 & 31.00 & 29.00 & 48.00 & 38.00 & 35.80 \\
\hline
\end{tabular}

Quadro 11 - Valores relativos à $1^{\mathrm{a}}$ medição dos parâmetros: área, perímetro e diâmetro maior, calculados através do programa Image Lab, de cada espécime, no período de 21 dias (grupo 4).

\begin{tabular}{|c|l|l|l|l|l|l|}
\hline espécime & \multicolumn{1}{|c|}{1} & \multicolumn{1}{c|}{2} & \multicolumn{1}{c|}{3} & \multicolumn{1}{c|}{4} & \multicolumn{1}{c|}{5} & média \\
\hline área & 896.50 & 1111.11 & 665.50 & 1147.61 & 791.50 & 922.44 \\
\hline perímetro & 203.98 & 216.75 & 144.66 & 171.19 & 160.66 & 179.45 \\
\hline diâmetro maior & 54.00 & 55.00 & 39.00 & 50.00 & 35.00 & 46.60 \\
\hline
\end{tabular}

Quadro 12 - Valores relativos à média final dos parâmetros: área, perímetro e diâmetro maior, calculados através do programa ImageLab, de cada medição, no período de 21 dias (grupo 4).

\begin{tabular}{|c|l|}
\hline área & 816.94 \\
\hline perímetro & 162.62 \\
\hline diâmetro maior & 43.60 \\
\hline
\end{tabular}




\section{Anexo 5}

Quadro 13 - Valores relativos à $1^{\mathrm{a}}$ medição dos parâmetros: área, perímetro e diâmetro maior, calculados através do programa Imagelab, de cada espécime, no período de 30 dias (grupo 5).

\begin{tabular}{|c|l|l|l|l|l|l|}
\hline espécime & \multicolumn{1}{c|}{1} & \multicolumn{1}{c|}{2} & \multicolumn{1}{c|}{3} & \multicolumn{1}{c|}{4} & \multicolumn{1}{c|}{5} & \multicolumn{1}{c|}{ média } \\
\hline área & 1270.00 & 488.50 & 1327.61 & 1007.00 & 1124.50 & 1043.52 \\
\hline perímetro & 230.59 & 104.18 & 226.30 & 201.88 & 215.63 & 195.72 \\
\hline diâmetro maior & 57.00 & 26.00 & 60.00 & 54.56 & 51.26 & 49.76 \\
\hline
\end{tabular}

Quadro 14 - Valores relativos à $2^{\mathrm{a}}$ medição dos parâmetros: área, perímetro e diâmetro maior, calculados através do programa Imagelab, de cada espécime, no período de 30 dias (grupo 5).

\begin{tabular}{|c|l|l|l|l|l|l|}
\hline espécime & \multicolumn{1}{c|}{1} & \multicolumn{1}{c|}{2} & \multicolumn{1}{c|}{3} & \multicolumn{1}{c|}{4} & \multicolumn{1}{c|}{5} & \multicolumn{1}{c|}{ média } \\
\hline área & 646.00 & 449.50 & 1184.00 & 1147.00 & 915.00 & 868.30 \\
\hline perímetro & 123.45 & 102.52 & 208.85 & 188.22 & 184.91 & 161.59 \\
\hline diâmetro maior & 34.00 & 26.00 & 59.46 & 52.00 & 46.00 & 43.49 \\
\hline
\end{tabular}

Quadro 15 - Valores relativos à $1^{\mathrm{a}}$ medição dos parâmetros: área, perímetro e diâmetro maior, calculados através do programa ImageLab, de cada espécime, no período de 30 dias (grupo 5).

\begin{tabular}{|c|l|l|l|l|l|l|}
\hline espécime & \multicolumn{1}{c|}{1} & \multicolumn{1}{c|}{2} & \multicolumn{1}{c|}{3} & \multicolumn{1}{c|}{4} & \multicolumn{1}{c|}{5} & \multicolumn{1}{c|}{ média } \\
\hline área & 1208.00 & 547.50 & 1211.50 & 945.50 & 944.11 & 971.32 \\
\hline perímetro & 218.91 & 115.69 & 193.78 & 181.98 & 187.92 & 179.65 \\
\hline diâmetro maior & 69.00 & 27.00 & 56.43 & 50.00 & 53.00 & 51.08 \\
\hline
\end{tabular}

Quadro 16 - Valores relativos à média final dos parâmetros: área, perímetro e diâmetro maior, calculados através do programa ImageLab, de cada medição, no período de 30 dias (grupo 5).

\begin{tabular}{|c|l|}
\hline área & 961.04 \\
\hline perímetro & 178.98 \\
\hline diâmetro maior & 48.11 \\
\hline
\end{tabular}




\section{Anexo 6}

Quadro 17 - Valores relativos à $1^{\mathrm{a}}$ medição dos parâmetros: área, perímetro e diâmetro maior, calculados através do programa Image Lab, de cada espécime, no período de 60dias (grupo 6).

\begin{tabular}{|c|l|l|l|l|l|l|}
\hline espécime & \multicolumn{1}{c|}{1} & \multicolumn{1}{c|}{2} & \multicolumn{1}{c|}{3} & \multicolumn{1}{c|}{4} & \multicolumn{1}{c|}{5} & \multicolumn{1}{c|}{ média } \\
\hline área & 836.50 & 1035.50 & 1381.00 & 647.00 & 634.00 & 913.30 \\
\hline perímetro & 154.66 & 178.87 & 196.56 & 130.08 & 112.62 & 154.56 \\
\hline diâmetro maior & 46.00 & 63.00 & 59.00 & 32.00 & 29.00 & 45.80 \\
\hline
\end{tabular}

Quadro 18 - Valores relativos à $2^{\mathrm{a}}$ medição dos parâmetros: área, perímetro e diâmetro maior, calculados através do programa ImageLab, de cada espécime, no período de 60 dias (grupo 6).

\begin{tabular}{|c|l|l|l|l|l|l|}
\hline espécime & \multicolumn{1}{c|}{1} & \multicolumn{1}{c|}{2} & \multicolumn{1}{c|}{3} & \multicolumn{1}{c|}{4} & \multicolumn{1}{c|}{5} & \multicolumn{1}{c|}{ média } \\
\hline área & 1086.50 & 1144.00 & 1159.94 & 1174.21 & 1134.50 & 1139.83 \\
\hline perímetro & 254.95 & 181.74 & 211.35 & 193.36 & 195.15 & 207.31 \\
\hline diâmetro maior & 49.00 & 62.00 & 58.00 & 60.00 & 64.00 & 58.60 \\
\hline
\end{tabular}

Quadro 19 - Valores relativos à $1^{\mathrm{a}}$ medição dos parâmetros: área, perímetro e diâmetro maior, calculados através do programa Image Lab, de cada espécime, no período de 60 dias (grupo 6).

\begin{tabular}{|c|l|l|l|l|l|l|}
\hline espécime & \multicolumn{1}{c|}{1} & \multicolumn{1}{c|}{2} & \multicolumn{1}{c|}{3} & \multicolumn{1}{c|}{4} & \multicolumn{1}{c|}{5} & \multicolumn{1}{c|}{ média } \\
\hline área & 795.00 & 1023.50 & 1331.50 & 951.11 & 1172.00 & 1054.62 \\
\hline perímetro & 171.84 & 193.15 & 190.46 & 158.95 & 185.74 & 180.03 \\
\hline diâmetro maior & 48.00 & 61.00 & 59.00 & 53.00 & 63.00 & 56.80 \\
\hline
\end{tabular}

Quadro 20 - Valores relativos à média final dos parâmetros: área, perímetro e diâmetro maior, calculados através do programa Imagelab, de cada medição, no período de 60 dias (grupo 6).

\begin{tabular}{|c|l|}
\hline \multicolumn{1}{|c|}{ área } & 1035.91 \\
\hline perímetro & 180.63 \\
\hline diâmetro maior & 53.73 \\
\hline
\end{tabular}




\section{Anexo 7}

Quadro 21 - Valores relativos à $1^{\mathrm{a}}$ medição dos parâmetros: área, perímetro e diâmetro maior, calculados através do programa Imagelab, de cada espécime, no período de 90 dias (grupo 7).

\begin{tabular}{|c|l|l|l|l|l|l|}
\hline espécime & \multicolumn{1}{c|}{1} & \multicolumn{1}{c|}{2} & \multicolumn{1}{c|}{3} & \multicolumn{1}{c|}{4} & \multicolumn{1}{c|}{5} & \multicolumn{1}{c|}{ média } \\
\hline área & 795.61 & 1292.00 & 1074.00 & 1164.50 & 979.50 & 1061.23 \\
\hline perímetro & 154.85 & 202.71 & 172.22 & 180.81 & 179.78 & 178.07 \\
\hline diâmetro maior & 51.00 & 64.00 & 52.00 & 51.00 & 55.00 & 54.60 \\
\hline
\end{tabular}

Quadro 22- Valores relativos à $2^{\mathrm{a}}$ medição dos parâmetros: área, perímetro e diâmetro maior, calculados através do programa ImageLab, de cada espécime, no período de 90 dias (grupo 7).

\begin{tabular}{|c|l|l|l|l|l|l|}
\hline espécime & \multicolumn{1}{c|}{1} & \multicolumn{1}{c|}{2} & \multicolumn{1}{c|}{3} & \multicolumn{1}{c|}{4} & \multicolumn{1}{c|}{5} & \multicolumn{1}{c|}{ média } \\
\hline área & 1122.50 & 1350.50 & 958.00 & 1175.11 & 1530.61 & 1227.34 \\
\hline perímetro & 192.66 & 228.61 & 197.39 & 197.58 & 203.82 & 204.01 \\
\hline diâmetro maior & 50.00 & 65.36 & 53.00 & 55.00 & 61.00 & 56.87 \\
\hline
\end{tabular}

Quadro 23 - Valores relativos à $1^{\mathrm{a}}$ medição dos parâmetros: área, perímetro e diâmetro maior, calculados através do programa Imagelab, de cada espécime, no período de 90 dias (grupo 7).

\begin{tabular}{|c|l|l|l|l|l|l|}
\hline espécime & \multicolumn{1}{c|}{1} & \multicolumn{1}{c|}{2} & \multicolumn{1}{c|}{3} & \multicolumn{1}{c|}{4} & \multicolumn{1}{c|}{5} & \multicolumn{1}{c|}{ média } \\
\hline área & 809.50 & 1043.00 & 767.50 & 982.00 & 1031.50 & 942.70 \\
\hline perímetro & 158.18 & 180.71 & 161.84 & 169.39 & 182.12 & 170.45 \\
\hline diâmetro maior & 49.00 & 51.00 & 51.00 & 49.00 & 60.00 & 52.00 \\
\hline
\end{tabular}

Quadro 24- Valores relativos à média final dos parâmetros: área, perímetro e diâmetro maior, calculados através do programa ImageLab, de cada medição, no período de 90 dias (grupo 7).

\begin{tabular}{|c|l|}
\hline área & 1077.09 \\
\hline perímetro & 184.17 \\
\hline diâmetro maior & 54.49 \\
\hline
\end{tabular}




\section{Anexo 8}

Quadro 25 - Análise microscópica subjetiva quanto: ao infiltrado inflamatório, às células clásticas, à cavidade cística, aos restos epiteliais de Malassez e ao tecido de granulação, no período de 3 dias (grupo 1), realizado pelo examinador $\mathrm{A}$.

\begin{tabular}{|c|c|c|c|c|c|c|}
\hline \multicolumn{7}{|c|}{ período experimental 3 dias - grupo 1} \\
\hline \multicolumn{2}{|c|}{ espécime } & 1 & 2 & 3 & 4 & 5 \\
\hline \multirow{4}{*}{ 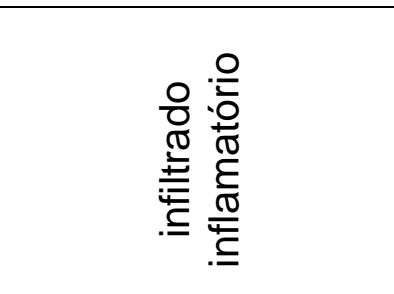 } & $\begin{array}{l}\text { tipo celular } \\
\text { predominante }\end{array}$ & MN & PMN & & & PMN \\
\hline & localização & $P$ & $\mathrm{P} / \mathrm{F}$ & & & $\mathrm{F}$ \\
\hline & distribuição & $\mathrm{d}$ & d & & & $f$ \\
\hline & intensidade & $\mathrm{D}$ & M & & & $\mathrm{D}$ \\
\hline \multirow{3}{*}{ 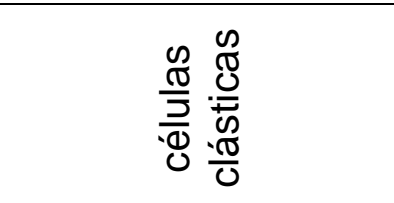 } & localização & $\mathrm{O}$ & $\mathrm{O}$ & & & $\mathrm{O}$ \\
\hline & intensidade & $\mathrm{D}$ & $\mathrm{D}$ & & & $\mathrm{D}$ \\
\hline & morfologia & $\mathrm{N}$ & $\mathrm{N}$ & & & $\mathrm{N}$ \\
\hline \multirow{2}{*}{$\begin{array}{l}\text { cavidade } \\
\text { cística }\end{array}$} & c/ epitélio de revestimento & - & - & & & - \\
\hline & s/ epitélio de revestimento & - & - & & & - \\
\hline $\begin{array}{c}\text { restos epiteliais } \\
\text { de Malassez }\end{array}$ & localização & $\mathrm{F}$ & $\mathrm{F}$ & & & $\mathrm{F}$ \\
\hline \multirow{2}{*}{ tecido de granulação } & próximo ao ápice & $\mathrm{X}$ & $\mathrm{X}$ & & & $\mathrm{X}$ \\
\hline & periferia da lesão & - & - & & & - \\
\hline
\end{tabular}

\section{LEGENDA}

-tipo celular predominante

localização

distribuição

intensidade

$$
\begin{aligned}
& \mathrm{MN}=\text { mononucleares } \\
& \mathrm{PMN}=\text { polimorfonucleares }
\end{aligned}
$$

$$
\mathrm{P}=\text { região periapical }
$$$$
\mathrm{F}=\text { região de furca }
$$

$$
\begin{aligned}
& f=\text { focal } \\
& d=\text { difusa }
\end{aligned}
$$

$$
\mathrm{D}=\text { discreta }
$$$$
M=\text { moderada }
$$$$
\mathrm{I}=\text { intensa }
$$

\section{-quanto às células clásticas:}

$$
\begin{aligned}
\text { localização } & C=\text { cemento } \\
& D=\text { dentina }
\end{aligned}
$$

intensidade

$$
\mathrm{D}=\text { discreta }
$$$$
\mathrm{M}=\text { moderada }
$$$$
\mathrm{I}=\text { intensa }
$$

morfologia

$\mathrm{N}=$ normal

$\mathrm{A}=$ alterada

-quanto aos restos epiteliais de Malassez:

$$
\begin{array}{ll}
\text { localização } & P=\text { região periapical } \\
& F=\text { região de furca }
\end{array}
$$

*Durante o processamento foram perdidos 2 espécimes deste grupo. 


\section{Anexo 9}

Quadro 26 - Análise microscópica subjetiva quanto: ao infiltrado inflamatório, às células clásticas, à cavidade cística, aos restos epiteliais de Malassez e ao tecido de granulação, no período de 3 dias (grupo 1), realizado pelo examinador B.

\begin{tabular}{|c|c|c|c|c|c|c|}
\hline \multicolumn{7}{|c|}{ período experimental 3 dias - grupo 1} \\
\hline \multicolumn{2}{|c|}{ espécime } & 1 & 2 & 3 & 4 & 5 \\
\hline \multirow{4}{*}{ 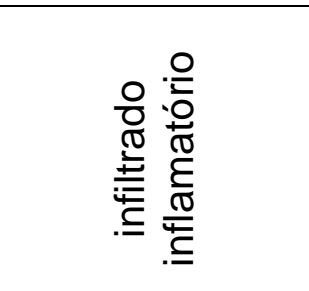 } & $\begin{array}{c}\text { tipo celular } \\
\text { predominante }\end{array}$ & MN & PMN & & & PMN \\
\hline & localização & $\mathrm{P}$ & $\mathrm{P} / \mathrm{F}$ & & & $\mathrm{F}$ \\
\hline & distribuição & $\mathrm{d}$ & $\mathrm{d}$ & & & $f$ \\
\hline & intensidade & $\mathrm{D}$ & $\mathrm{D}$ & & & $\mathrm{D}$ \\
\hline \multirow{3}{*}{ 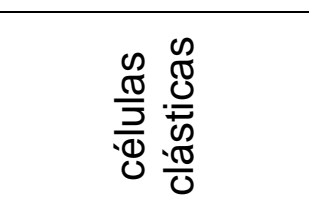 } & localização & $\mathrm{O}$ & $\mathrm{O}$ & & & $\mathrm{O}$ \\
\hline & intensidade & $\mathrm{D}$ & $\mathrm{M}$ & & & $\mathrm{D}$ \\
\hline & morfologia & $\mathrm{N}$ & $\mathrm{N}$ & & & $\mathrm{N}$ \\
\hline \multirow{2}{*}{$\begin{array}{l}\text { cavidade } \\
\text { cística }\end{array}$} & $\begin{array}{l}\text { c/ epitélio de } \\
\text { revestimento }\end{array}$ & - & - & & & - \\
\hline & $\begin{array}{l}\text { s/ epitélio de } \\
\text { revestimento }\end{array}$ & - & - & & & - \\
\hline $\begin{array}{c}\text { restos epiteliais } \\
\text { de Malassez }\end{array}$ & localização & $\mathrm{F}$ & $\mathrm{F}$ & & & $\mathrm{F}$ \\
\hline \multirow{2}{*}{$\begin{array}{c}\text { tecido de } \\
\text { granulação }\end{array}$} & próximo ao ápice & $\mathrm{X}$ & $\mathrm{X}$ & & & $\mathrm{X}$ \\
\hline & periferia da lesão & - & - & & & - \\
\hline
\end{tabular}

\section{LEGENDA}

-tipo celular predominante

localização

distribuição

\section{$\mathrm{MN}=$ mononucleares \\ $\mathrm{PMN}=$ polimorfonucleares}

$\mathrm{P}=$ região periapical

$\mathrm{F}=$ região de furca

$f=$ focal

$\mathrm{d}=$ difusa

$\mathrm{D}=$ discreta

$M=$ moderada

$\mathrm{I}$ = intensa -quanto às células clásticas:

$$
\begin{array}{cl}
\text { localização } & \begin{array}{l}
\mathrm{C}=\text { cemento } \\
\end{array} \\
& \mathrm{D}=\text { dentina } \\
\text { intensidade } & \mathrm{D}=\text { discreta } \\
& \mathrm{M}=\text { moderada } \\
& \mathrm{I}=\text { intensa } \\
\text { morfologia } & \mathrm{N}=\text { normal } \\
& \mathrm{A}=\text { alterada }
\end{array}
$$

-quanto aos restos epiteliais de Malassez:

$$
\begin{array}{ll}
\text { localização } & P=\text { região periapical } \\
& F=\text { região de furca }
\end{array}
$$

*Durante o processamento foram perdidos 2 espécimes deste grupo. 


\section{Anexo 10}

Quadro 27 - Análise microscópica subjetiva quanto: ao infiltrado inflamatório, às células clásticas, à cavidade cística, aos restos epiteliais de Malassez e ao tecido de granulação, no período de 7 dias (grupo 2), realizado pelo examinador $\mathrm{A}$.

\begin{tabular}{|c|c|c|c|c|c|c|}
\hline \multicolumn{7}{|c|}{ período experimental 7 dias - grupo 2} \\
\hline \multicolumn{2}{|c|}{ espécime } & 1 & 2 & 3 & 4 & 5 \\
\hline \multirow{4}{*}{ 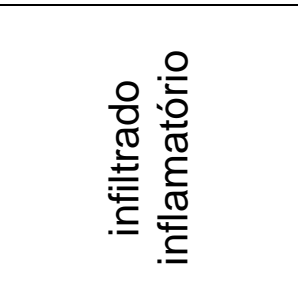 } & $\begin{array}{l}\text { tipo celular } \\
\text { predominante }\end{array}$ & PMN & & PMN & PMN & PMN \\
\hline & localização & $\mathrm{P} / \mathrm{F}$ & & $\mathrm{P} / \mathrm{F}$ & $\mathrm{P} / \mathrm{F}$ & $\mathrm{P}$ \\
\hline & distribuição & $f$ & & $\mathrm{~d}$ & $\mathrm{~d}$ & $\mathrm{~d}$ \\
\hline & intensidade & M & & M & M & $\mathrm{M}$ \\
\hline \multirow{3}{*}{ 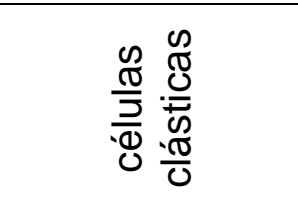 } & localização & $\mathrm{O} / \mathrm{C}$ & & $\mathrm{O} / \mathrm{C} / \mathrm{D}$ & $\mathrm{O} / \mathrm{C}$ & $\mathrm{O} / \mathrm{C}$ \\
\hline & intensidade & $\mathrm{D}$ & & $\mathrm{M}$ & $\mathrm{M}$ & $\mathrm{M}$ \\
\hline & morfologia & $\mathrm{N}$ & & $\mathrm{N}$ & $\mathrm{N}$ & $\mathrm{N}$ \\
\hline \multirow{2}{*}{$\begin{array}{l}\text { cavidade } \\
\text { cística }\end{array}$} & c/ epitélio de revestimento & - & & - & - & - \\
\hline & s/ epitélio de revestimento & - & & - & $\mathrm{X}$ & - \\
\hline $\begin{array}{c}\text { restos epiteliais } \\
\text { de Malassez }\end{array}$ & localização & $\mathrm{F}$ & & $\mathrm{F}$ & - & $\mathrm{F}$ \\
\hline \multirow{2}{*}{$\begin{array}{c}\text { tecido de } \\
\text { granulação }\end{array}$} & próximo ao ápice & $\mathrm{X}$ & & $\mathrm{X}$ & - & - \\
\hline & periferia da lesão & $\mathrm{X}$ & & $\mathrm{X}$ & $\mathrm{X}$ & - \\
\hline
\end{tabular}

LEGENDA

-tipo celular predominante

localização

distribuição

intensidade
$\mathrm{MN}=$ mononucleares

$\mathrm{PMN}=$ polimorfonucleares

$P=$ região periapical
$F=$ região de furca

$f=$ focal

$\mathrm{d}=$ difusa

$\mathrm{D}=$ discreta

$M=$ moderada

$\mathrm{I}=$ intensa -quanto às células clásticas:

$$
\begin{array}{ll} 
& O=\text { osso } \\
\text { localização } & C=\text { cemento } \\
& D=\text { dentina }
\end{array}
$$

intensidade

$\mathrm{D}=$ discreta

$\mathrm{M}=$ moderada

$\mathrm{I}$ = intensa

morfologia

$\mathrm{N}=$ normal

$\mathrm{A}=$ alterada

-quanto aos restos epiteliais de Malassez:
localização
$P=$ região periapical
$F=$ região de furca

*Durante o processamento foi perdido 1 espécime deste grupo. 


\section{Anexo 11}

Quadro 28 - Análise microscópica subjetiva quanto: ao infiltrado inflamatório, às células clásticas, à cavidade cística, aos restos epiteliais de Malassez e ao tecido de granulação, no período de 7 dias (grupo 2), realizado pelo examinador B.

\begin{tabular}{|c|c|c|c|c|c|c|}
\hline \multicolumn{7}{|c|}{ período experimental 7 dias - grupo 2} \\
\hline \multicolumn{2}{|c|}{ espécime } & 1 & 2 & 3 & 4 & 5 \\
\hline \multirow{4}{*}{ 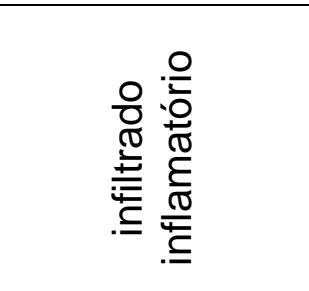 } & $\begin{array}{c}\text { tipo celular } \\
\text { predominante }\end{array}$ & PMN & & PMN & PMN & PMN \\
\hline & localização & $\mathrm{P} / \mathrm{F}$ & & $\mathrm{P} / \mathrm{F}$ & $\mathrm{P} / \mathrm{F}$ & $\mathrm{P}$ \\
\hline & distribuição & $f$ & & $\mathrm{~d}$ & $\mathrm{~d}$ & $\mathrm{~d}$ \\
\hline & intensidade & M & & M & M & $\mathrm{D}$ \\
\hline \multirow{3}{*}{ 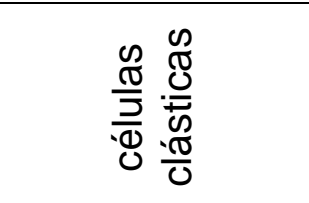 } & localização & $\mathrm{O} / \mathrm{C}$ & & $\mathrm{O} / \mathrm{C} / \mathrm{D}$ & $\mathrm{O} / \mathrm{C}$ & $\mathrm{O} / \mathrm{C}$ \\
\hline & intensidade & $\mathrm{D}$ & & $M$ & $M$ & $\mathrm{D}$ \\
\hline & morfologia & $\mathrm{N}$ & & $\mathrm{N}$ & $\mathrm{N}$ & $\mathrm{N}$ \\
\hline \multirow{2}{*}{$\begin{array}{l}\text { cavidade } \\
\text { cística }\end{array}$} & c/ epitélio de revestimento & - & & - & - & - \\
\hline & s/ epitélio de revestimento & - & & - & $X$ & - \\
\hline $\begin{array}{c}\text { restos epiteliais } \\
\text { de Malassez }\end{array}$ & localização & $F$ & & $F$ & - & $F$ \\
\hline \multirow{2}{*}{$\begin{array}{c}\text { tecido de } \\
\text { granulação }\end{array}$} & próximo ao ápice & $\mathrm{X}$ & & $\mathrm{X}$ & - & - \\
\hline & periferia da lesão & $\mathrm{X}$ & & $\mathrm{X}$ & $X$ & - \\
\hline
\end{tabular}

\section{LEGENDA}

-tipo celular predominante

localização

distribuição

intensidade
$\mathrm{MN}=$ mononucleares

$\mathrm{PMN}=$ polimorfonucleares

$$
\begin{aligned}
& P=\text { região periapical } \\
& F=\text { região de furca }
\end{aligned}
$$

$$
f=\text { focal }
$$$$
\mathrm{d}=\text { difusa }
$$$$
\mathrm{D}=\text { discreta }
$$$$
\mathrm{M}=\text { moderada }
$$$$
\text { I = intensa }
$$

-quanto às células clásticas:

$$
\begin{aligned}
& \mathrm{O}=\text { osso } \\
& \mathrm{C}=\text { cemento } \\
& \mathrm{D}=\text { dentina } \\
& \mathrm{D}=\text { discreta } \\
& \text { intensidade } \\
& \mathrm{M}=\text { moderada } \\
& \text { I = intensa } \\
& \text { morfologia } \\
& \mathrm{N}=\text { normal } \\
& \mathrm{A}=\text { alterada }
\end{aligned}
$$

-quanto aos restos epiteliais de Malassez:

$$
\begin{array}{ll}
\text { localização } & P=\text { região periapical } \\
& F=\text { região de furca }
\end{array}
$$

*Durante o processamento foi perdido 1 espécime deste grupo. 


\section{Anexo 12}

Quadro 29 - Análise microscópica subjetiva quanto: ao infiltrado inflamatório, às células clásticas, à cavidade cística, aos restos epiteliais de Malassez e ao tecido de granulação, no período de 14 dias (grupo 3), realizado pelo examinador $\mathrm{A}$.

\begin{tabular}{|c|c|c|c|c|c|c|}
\hline \multicolumn{7}{|c|}{ período experimental 14 dias - grupo 3} \\
\hline \multicolumn{2}{|c|}{ espécime } & 1 & 2 & 3 & 4 & 5 \\
\hline \multirow{4}{*}{ 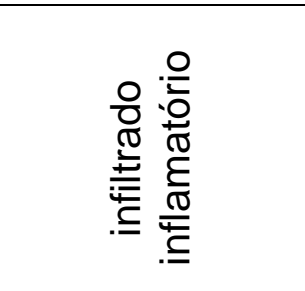 } & $\begin{array}{c}\text { tipo celular } \\
\text { predominante }\end{array}$ & PMN & PMN & PMN & PMN & PMN \\
\hline & localização & $\mathrm{P} / \mathrm{F}$ & $\mathrm{P} / \mathrm{F}$ & $\mathrm{F}$ & $\mathrm{P} / \mathrm{F}$ & $\mathrm{P} / \mathrm{F}$ \\
\hline & distribuição & $f$ & $\mathrm{~d}$ & $\mathrm{~d}$ & $\mathrm{~d}$ & $\mathrm{~d}$ \\
\hline & intensidade & $M$ & $\mathrm{M}$ & $\mathrm{M}$ & M & M \\
\hline \multirow{3}{*}{ 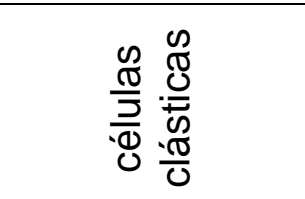 } & localização & $\mathrm{O}$ & $\mathrm{O} / \mathrm{C}$ & $\mathrm{O} / \mathrm{C}$ & $\mathrm{O} / \mathrm{C}$ & $\mathrm{O} / \mathrm{C}$ \\
\hline & intensidade & $\mathrm{D}$ & $\mathrm{D}$ & $\mathrm{M}$ & $\mathrm{M}$ & $\mathrm{M}$ \\
\hline & morfologia & $\mathrm{N}$ & $\mathrm{N}$ & $\mathrm{N}$ & $\mathrm{N}$ & $\mathrm{N}$ \\
\hline \multirow{2}{*}{$\begin{array}{l}\text { cavidade } \\
\text { cística }\end{array}$} & c/ epitélio de revestimento & - & - & $\mathrm{X}$ & - & $\mathrm{X}$ \\
\hline & s/ epitélio de revestimento & $\mathrm{X}$ & $\mathrm{X}$ & - & $X$ & - \\
\hline $\begin{array}{l}\text { restos epiteliais } \\
\text { de Malassez }\end{array}$ & localização & $\mathrm{F}$ & $P$ & $F$ & $P$ & $P$ \\
\hline \multirow{2}{*}{$\begin{array}{c}\text { tecido de } \\
\text { granulação }\end{array}$} & próximo ao ápice & $\mathrm{X}$ & $\mathrm{X}$ & - & - & - \\
\hline & periferia da lesão & $\mathrm{X}$ & - & $\mathrm{X}$ & $\bar{X}$ & $\mathrm{X}$ \\
\hline
\end{tabular}

LEGENDA

-tipo celular

predominante

localização

distribuição

intensidade
$\mathrm{MN}=$ mononucleares

PMN =polimorfonucleares

$$
\mathrm{P}=\text { região periapical }
$$$$
\mathrm{F}=\text { região de furca }
$$

$$
\begin{aligned}
& f=\text { focal } \\
& d=\text { difusa } \\
& D=\text { discreta } \\
& M=\text { moderada } \\
& I=\text { intensa }
\end{aligned}
$$

quanto aos restos epiteliais de Malassez: localização -quanto às células clásticas:

$\begin{array}{ll} & \\ \text { localização } & \mathrm{C}=\text { osso } \\ & \mathrm{D}=\text { cemento } \\ & \end{array}$

intensidade

$\mathrm{D}=$ discreta

$\mathrm{M}=$ moderada

$\mathrm{I}=$ intensa

morfologia

$\mathrm{N}=$ normal

$\mathrm{A}=$ alterada 


\section{Anexo 13}

Quadro 30 - Análise microscópica subjetiva quanto: ao infiltrado inflamatório, às células clásticas, à cavidade cística, aos restos epiteliais de Malassez e ao tecido de granulação, no período de 14 dias (grupo 3), realizado pelo examinador B.

\begin{tabular}{|c|c|c|c|c|c|c|}
\hline \multicolumn{7}{|c|}{ período experimental 14 dias - grupo 3} \\
\hline \multicolumn{2}{|c|}{ espécime } & 1 & 2 & 3 & 4 & 5 \\
\hline \multirow{4}{*}{ 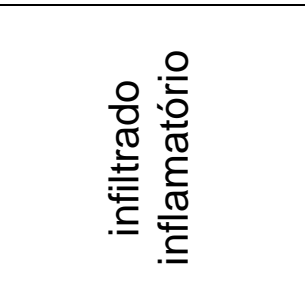 } & $\begin{array}{c}\text { tipo celular } \\
\text { predominante }\end{array}$ & PMN & PMN & PMN & PMN & PMN \\
\hline & localização & $\mathrm{P} / \mathrm{F}$ & $\mathrm{P} / \mathrm{F}$ & $\mathrm{F}$ & $\mathrm{P} / \mathrm{F}$ & $\mathrm{P} / \mathrm{F}$ \\
\hline & distribuição & $f$ & $\mathrm{~d}$ & $\mathrm{~d}$ & d & d \\
\hline & intensidade & $\mathrm{D}$ & M & M & M & M \\
\hline \multirow{3}{*}{ 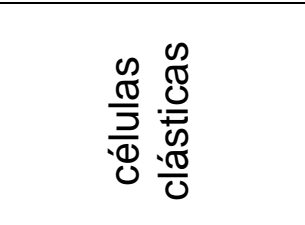 } & localização & $\mathrm{O}$ & $\mathrm{O} / \mathrm{C}$ & $\mathrm{O} / \mathrm{C}$ & $\mathrm{O} / \mathrm{C}$ & $\mathrm{O} / \mathrm{C}$ \\
\hline & intensidade & $\mathrm{D}$ & $\mathrm{D}$ & $\mathrm{D}$ & M & M \\
\hline & morfologia & $\mathrm{N}$ & $\mathrm{N}$ & $\mathrm{N}$ & $\mathrm{N}$ & $\mathrm{N}$ \\
\hline \multirow{2}{*}{$\begin{array}{l}\text { cavidade } \\
\text { cística }\end{array}$} & c/ epitélio de revestimento & - & - & $X$ & - & $\mathrm{X}$ \\
\hline & s/ epitélio de revestimento & $X$ & $X$ & - & $X$ & - \\
\hline $\begin{array}{l}\text { restos epiteliais } \\
\text { de Malassez }\end{array}$ & localização & $\mathrm{F}$ & $P$ & $\mathrm{~F}$ & $P$ & $P$ \\
\hline \multirow{2}{*}{$\begin{array}{l}\text { tecido de } \\
\text { granulação }\end{array}$} & próximo ao ápice & $\mathrm{X}$ & $x$ & - & - & - \\
\hline & periferia da lesão & $\mathrm{X}$ & - & $\mathrm{X}$ & $X$ & $\mathrm{X}$ \\
\hline
\end{tabular}

\section{LEGENDA}

-tipo celular predominante

localização

distribuição

intensidade
$\mathrm{MN}=$ mononucleares PMN =polimorfonucleares

$$
P=\text { região periapical }
$$$$
\mathrm{F}=\text { região de furca }
$$

$$
\begin{aligned}
& f=\text { focal } \\
& d=\text { difusa } \\
& D=\text { discreta } \\
& M=\text { moderada } \\
& I=\text { intensa }
\end{aligned}
$$

-quanto aos restos epiteliais de Malassez:

$$
\begin{array}{ll}
\text { localização } & P=\text { região periapica } \\
& F=\text { região de furca }
\end{array}
$$

-quanto às células clásticas:

$$
\begin{aligned}
& \mathrm{O}=\text { osso } \\
& \mathrm{C}=\text { cemento } \\
& \mathrm{D}=\text { dentina } \\
& \mathrm{D}=\text { discreta } \\
& \mathrm{M}=\text { moderada } \\
& \mathrm{I}=\text { intensa } \\
& \text { morfologia } \quad \mathrm{N}=\text { normal } \\
& \mathrm{A}=\text { alterada }
\end{aligned}
$$




\section{Anexo 14}

Quadro 31 - Análise microscópica subjetiva quanto: ao infiltrado inflamatório, às células clásticas, à cavidade cística, aos restos epiteliais de Malassez e ao tecido de granulação, no período de 21 dias (grupo 4), realizado pelo examinador $\mathrm{A}$.

\begin{tabular}{|c|c|c|c|c|c|c|}
\hline \multicolumn{7}{|c|}{ período experimental 21 dias - grupo 4} \\
\hline \multicolumn{2}{|c|}{ espécime } & 1 & 2 & 3 & 4 & 5 \\
\hline \multirow{4}{*}{ 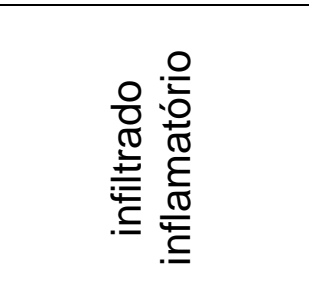 } & $\begin{array}{l}\text { tipo celular } \\
\text { predominante }\end{array}$ & PMN & PMN & PMN & PMN & PMN \\
\hline & localização & $\mathrm{P} / \mathrm{F}$ & $\mathrm{P} / \mathrm{F}$ & $\mathrm{P} / \mathrm{F}$ & $\mathrm{P} / \mathrm{F}$ & $\mathrm{F}$ \\
\hline & distribuição & $f$ & $\mathrm{~d}$ & $\mathrm{~d}$ & d & $\mathrm{d}$ \\
\hline & intensidade & $\mathrm{M}$ & $M$ & $M$ & $\mathrm{M}$ & M \\
\hline \multirow{3}{*}{ 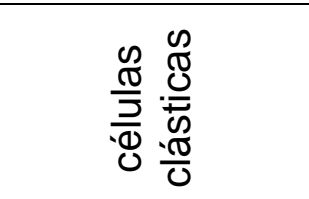 } & localização & $\mathrm{O} / \mathrm{C}$ & $\mathrm{O} / \mathrm{C}$ & $\mathrm{O}$ & $\mathrm{O}$ & $\mathrm{O} / \mathrm{C}$ \\
\hline & intensidade & $\mathrm{D}$ & $\mathrm{D}$ & $\mathrm{D}$ & $\mathrm{M}$ & $\mathrm{D}$ \\
\hline & morfologia & $\mathrm{N}$ & $\mathrm{N}$ & $\mathrm{N}$ & $\mathrm{N}$ & $\mathrm{N}$ \\
\hline \multirow{2}{*}{$\begin{array}{l}\text { cavidade } \\
\text { cística }\end{array}$} & c/ epitélio de revestimento & - & $\mathrm{X}_{\mathrm{F}}$ & $\mathrm{X}_{\mathrm{F}}$ & - & - \\
\hline & s/ epitélio de revestimento & - & $X_{P}$ & - & - & - \\
\hline $\begin{array}{c}\text { restos epiteliais } \\
\text { de Malassez }\end{array}$ & localização & $F$ & $P$ & - & $\mathrm{F}$ & $\mathrm{F}$ \\
\hline \multirow{2}{*}{$\begin{array}{c}\text { tecido de } \\
\text { granulação }\end{array}$} & próximo ao ápice & - & - & - & - & - \\
\hline & periferia da lesão & $\mathrm{X}$ & $\mathrm{X}$ & - & $\mathrm{X}$ & $\mathrm{X}$ \\
\hline
\end{tabular}

\section{LEGENDA}

-tipo celular

predominante

localização

distribuição

intensidade
$\mathrm{MN}=$ mononucleares

$\mathrm{PMN}=$ polimorfonucleares

$$
\mathrm{P}=\text { região periapical }
$$$$
\mathrm{F}=\text { região de furca }
$$

$$
\begin{aligned}
& f=\text { focal } \\
& d=\text { difusa } \\
& D=\text { discreta } \\
& M=\text { moderada } \\
& I=\text { intensa }
\end{aligned}
$$

quanto aos restos epiteliais de Malassez:

$$
\begin{array}{ll}
\text { localização } & P=\text { região periapical } \\
& F=\text { região de furca }
\end{array}
$$

-quanto às células clásticas:

$$
\begin{array}{ll} 
& O=\text { osso } \\
\text { Iocalização } & C=\text { cemento } \\
& D=\text { dentina }
\end{array}
$$

intensidade

$$
\mathrm{D}=\text { discreta }
$$$$
\mathrm{M}=\text { moderada }
$$$$
\mathrm{I}=\text { intensa }
$$

morfologia

$\mathrm{N}=$ normal

$\mathrm{A}=$ alterada 


\section{Anexo 15}

Quadro 32 - Análise microscópica subjetiva quanto: ao infiltrado inflamatório, às células clásticas, à cavidade cística, aos restos epiteliais de Malassez e ao tecido de granulação, no período de 21 dias (grupo 4), realizado pelo examinador $\mathrm{B}$.

\begin{tabular}{|c|c|c|c|c|c|c|}
\hline \multicolumn{7}{|c|}{ período experimental 21 dias - grupo 4} \\
\hline \multicolumn{2}{|c|}{ espécime } & 1 & 2 & 3 & 4 & 5 \\
\hline \multirow{4}{*}{ 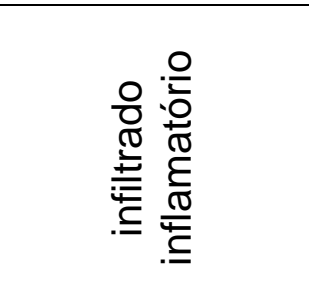 } & $\begin{array}{l}\text { tipo celular } \\
\text { predominante }\end{array}$ & PMN & PMN & PMN & PMN & PMN \\
\hline & localização & $\mathrm{P} / \mathrm{F}$ & $\mathrm{P} / \mathrm{F}$ & $\mathrm{P} / \mathrm{F}$ & $\mathrm{P} / \mathrm{F}$ & $F$ \\
\hline & distribuição & $f$ & d & d & $\mathrm{d}$ & $d$ \\
\hline & intensidade & M & $\mathrm{M}$ & M & M & M \\
\hline \multirow{3}{*}{ 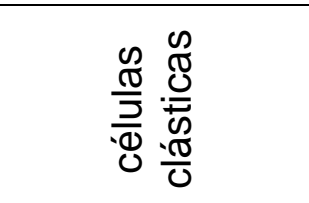 } & localização & $\mathrm{O} / \mathrm{C}$ & $\mathrm{O} / \mathrm{C}$ & $\mathrm{O}$ & $\mathrm{O}$ & $\mathrm{O} / \mathrm{C}$ \\
\hline & intensidade & $\mathrm{D}$ & $\mathrm{D}$ & $\mathrm{D}$ & $\mathrm{M}$ & $\mathrm{D}$ \\
\hline & morfologia & $\mathrm{N}$ & $\mathrm{N}$ & $\mathrm{N}$ & $\mathrm{N}$ & $\mathrm{N}$ \\
\hline \multirow{2}{*}{$\begin{array}{l}\text { cavidade } \\
\text { cística }\end{array}$} & c/ epitélio de revestimento & - & $X_{F}$ & $X_{F}$ & - & - \\
\hline & s/ epitélio de revestimento & - & $X_{P}$ & - & - & - \\
\hline $\begin{array}{c}\text { restos epiteliais } \\
\text { de Malassez }\end{array}$ & localização & $\mathrm{F}$ & $P$ & - & $F$ & $F$ \\
\hline \multirow{2}{*}{$\begin{array}{c}\text { tecido de } \\
\text { granulação }\end{array}$} & próximo ao ápice & - & - & - & - & - \\
\hline & periferia da lesão & $\mathrm{X}$ & $\mathrm{X}$ & - & $\mathrm{X}$ & $X$ \\
\hline
\end{tabular}

\section{LEGENDA}

-tipo celular

predominante

localização

distribuição

intensidade
$\mathrm{MN}=$ mononucleares

PMN =polimorfonucleares

$$
P=\text { região periapical }
$$$$
\mathrm{F}=\text { região de furca }
$$

$$
f=\text { focal }
$$$$
\mathrm{d}=\text { difusa }
$$$$
\mathrm{D}=\text { discreta }
$$$$
\mathrm{M}=\text { moderada }
$$$$
\mathrm{I}=\text { intensa }
$$

-quanto às células clásticas:

$$
\begin{aligned}
& \begin{array}{ll}
\text { localização } & \mathrm{C}=\text { osso } \\
\text { lomento }
\end{array} \\
& \mathrm{D}=\text { dentina } \\
& \text { intensidade } \\
& \mathrm{D}=\text { discreta } \\
& \mathrm{M}=\text { moderada } \\
& \text { I = intensa } \\
& \text { morfologia } \\
& \mathrm{N}=\text { normal } \\
& A=\text { alterada }
\end{aligned}
$$

-quanto aos restos epiteliais de Malassez: Iocalização 


\section{Anexo 16}

Quadro 33 - Análise microscópica subjetiva quanto: ao infiltrado inflamatório, às células clásticas, à cavidade cística, aos restos epiteliais de Malassez e ao tecido de granulação, no período de 30 dias (grupo 5), realizado pelo examinador $\mathrm{A}$.

\begin{tabular}{|c|c|c|c|c|c|c|}
\hline \multicolumn{7}{|c|}{ período experimental 30 dias - grupo 5} \\
\hline \multicolumn{2}{|r|}{ espécime } & 1 & 2 & 3 & 4 & 5 \\
\hline \multirow{4}{*}{ 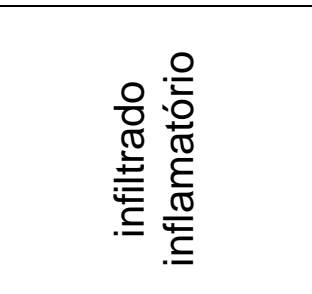 } & $\begin{array}{l}\text { tipo celular } \\
\text { predominante }\end{array}$ & PMN & PMN & PMN & PMN & PMN \\
\hline & localização & $\mathrm{P} / \mathrm{F}$ & $\mathrm{P}$ & $\mathrm{P} / \mathrm{F}$ & $\mathrm{P} / \mathrm{F}$ & $\mathrm{P} / \mathrm{F}$ \\
\hline & distribuição & $\mathrm{d}$ & $f$ & $\mathrm{~d}$ & $\mathrm{~d}$ & $\mathrm{~d}$ \\
\hline & intensidade & M & M & I & M & M \\
\hline \multirow{3}{*}{ 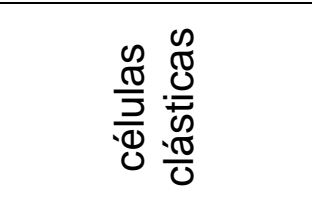 } & localização & $\mathrm{O} / \mathrm{C}$ & $\mathrm{O} / \mathrm{C}$ & $\mathrm{O}$ & $\mathrm{O} / \mathrm{C} / \mathrm{D}$ & $\mathrm{O} / \mathrm{C} / \mathrm{D}$ \\
\hline & intensidade & $\mathrm{M}$ & $\mathrm{M}$ & $\mathrm{M}$ & $\mathrm{M}$ & $\mathrm{M}$ \\
\hline & morfologia & $\mathrm{N}$ & $\mathrm{N}$ & $\mathrm{N}$ & $\mathrm{N}$ & $\mathrm{N}$ \\
\hline \multirow{2}{*}{$\begin{array}{l}\text { cavidade } \\
\text { cística }\end{array}$} & c/ epitélio de revestimento & $\mathrm{X}$ & $X_{F}$ & $\mathrm{X}$ & $\mathrm{X}$ & $\mathrm{X}$ \\
\hline & s/ epitélio de revestimento & - & - & - & - & - \\
\hline $\begin{array}{l}\text { restos epiteliais } \\
\text { de Malassez }\end{array}$ & localização & $P$ & $\mathrm{P} / \mathrm{F}$ & $F$ & $\mathrm{P} / \mathrm{F}$ & $\mathrm{F}$ \\
\hline \multirow{2}{*}{$\begin{array}{c}\text { tecido de } \\
\text { granulação }\end{array}$} & próximo ao ápice & $\mathrm{X}$ & $\mathrm{X}$ & $\mathrm{X}$ & $\mathrm{X}$ & $\mathrm{X}$ \\
\hline & periferia da lesão & $\bar{X}$ & $\mathrm{X}$ & $\mathrm{X}$ & $\mathrm{X}$ & $\bar{X}$ \\
\hline
\end{tabular}

LEGENDA

-tipo celular

predominante

localização

distribuição

intensidade
$\mathrm{MN}=$ mononucleares

PMN =polimorfonucleares

$$
\mathrm{P}=\text { região periapical }
$$$$
\mathrm{F}=\text { região de furca }
$$

$$
\begin{aligned}
& f=\text { focal } \\
& d=\text { difusa } \\
& D=\text { discreta } \\
& M=\text { moderada } \\
& I=\text { intensa }
\end{aligned}
$$

quanto aos restos epiteliais de Malassez: localização -quanto às células clásticas:

\begin{tabular}{ll}
\multirow{2}{*}{ localização } & $\mathrm{O}=$ osso \\
& $\mathrm{C}=$ cemento \\
& $\mathrm{D}=$ dentina
\end{tabular}

intensidade

$\mathrm{D}=$ discreta

$\mathrm{M}=$ moderada

$\mathrm{I}=$ intensa

morfologia

$\mathrm{N}=$ normal

$A=$ alterada 


\section{Anexo 17}

Quadro 34 - Análise microscópica subjetiva quanto: ao infiltrado inflamatório, às células clásticas, à cavidade cística, aos restos epiteliais de Malassez e ao tecido de granulação, no período de 30 dias (grupo 5), realizado pelo examinador B.

\begin{tabular}{|c|c|c|c|c|c|c|}
\hline \multicolumn{7}{|c|}{ período experimental 30 dias - grupo 5} \\
\hline \multicolumn{2}{|r|}{ espécime } & 1 & 2 & 3 & 4 & 5 \\
\hline \multirow{4}{*}{ 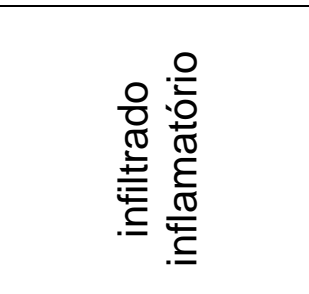 } & $\begin{array}{c}\text { tipo celular } \\
\text { predominante }\end{array}$ & PMN & PMN & PMN & PMN & PMN \\
\hline & localização & $\mathrm{P} / \mathrm{F}$ & $P$ & $\mathrm{P} / \mathrm{F}$ & $\mathrm{P} / \mathrm{F}$ & $\mathrm{P} / \mathrm{F}$ \\
\hline & distribuição & $\mathrm{d}$ & $f$ & $\mathrm{~d}$ & $\mathrm{~d}$ & $\mathrm{~d}$ \\
\hline & intensidade & $\mathrm{M}$ & M & I & $\mathrm{D}$ & $M$ \\
\hline \multirow{3}{*}{ 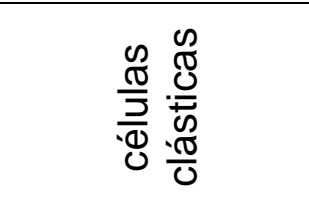 } & localização & $\mathrm{O} / \mathrm{C}$ & $\mathrm{O} / \mathrm{C}$ & $\mathrm{O}$ & $\mathrm{O} / \mathrm{C} / \mathrm{D}$ & $\mathrm{O} / \mathrm{C} / \mathrm{D}$ \\
\hline & intensidade & $M$ & $M$ & $M$ & $\mathrm{D}$ & $M$ \\
\hline & morfologia & $\mathrm{N}$ & $\mathrm{N}$ & $\mathrm{N}$ & $\mathrm{N}$ & $\mathrm{N}$ \\
\hline \multirow{2}{*}{$\begin{array}{l}\text { cavidade } \\
\text { cística }\end{array}$} & c/ epitélio de revestimento & $\mathrm{X}$ & $\mathrm{X}_{\mathrm{F}}$ & $\mathrm{X}$ & $\mathrm{X}$ & $\mathrm{X}$ \\
\hline & s/ epitélio de revestimento & - & - & - & - & - \\
\hline $\begin{array}{c}\text { restos epiteliais } \\
\text { de Malassez }\end{array}$ & localização & $P$ & $\mathrm{P} / \mathrm{F}$ & $\mathrm{F}$ & $\mathrm{P} / \mathrm{F}$ & $\mathrm{F}$ \\
\hline \multirow{2}{*}{$\begin{array}{c}\text { tecido de } \\
\text { granulação }\end{array}$} & próximo ao ápice & $\mathrm{X}$ & $\mathrm{X}$ & $\mathrm{X}$ & $\mathrm{X}$ & $\mathrm{X}$ \\
\hline & periferia da lesão & $\bar{X}$ & $\bar{X}$ & $\mathrm{X}$ & $X$ & $\bar{X}$ \\
\hline
\end{tabular}

LEGENDA

-tipo celular

predominante

localização

distribuição

intensidade
$\mathrm{MN}=$ mononucleares

PMN =polimorfonucleares

$$
\mathrm{P}=\text { região periapical }
$$$$
F=\text { região de furca }
$$

$$
f=\text { focal }
$$$$
\mathrm{d}=\text { difusa }
$$$$
\mathrm{D}=\text { discreta }
$$$$
\mathrm{M}=\text { moderada }
$$$$
\mathrm{I}=\text { intensa }
$$

-quanto às células clásticas:

$$
\begin{array}{ll} 
& O=\text { osso } \\
\text { localização } & C=\text { cemento } \\
& D=\text { dentina }
\end{array}
$$

intensidade

$$
\mathrm{D}=\text { discreta }
$$$$
\mathrm{M}=\text { moderada }
$$$$
\text { I = intensa }
$$

morfologia

$\mathrm{N}=$ normal

$A=$ alterada

-quanto aos restos epiteliais de Malassez: localização 


\section{Anexo 18}

Quadro 35 - Análise microscópica subjetiva quanto: ao infiltrado inflamatório, às células clásticas, à cavidade cística, aos restos epiteliais de Malassez e ao tecido de granulação, no período de 60 dias (grupo 6), realizado pelo examinador $\mathrm{A}$.

\begin{tabular}{|c|c|c|c|c|c|c|}
\hline \multicolumn{7}{|c|}{ período experimental 60 dias - grupo 6} \\
\hline \multicolumn{2}{|c|}{ espécime } & 1 & 2 & 3 & 4 & 5 \\
\hline \multirow{4}{*}{ 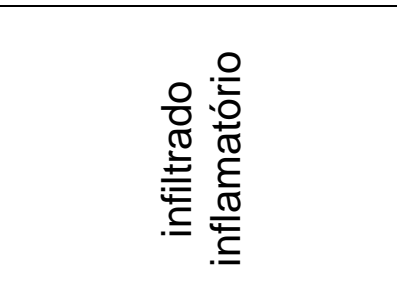 } & $\begin{array}{l}\text { tipo celular } \\
\text { predominante }\end{array}$ & PMN & PMN & MN & MN & PMN \\
\hline & localização & $P$ & $\mathrm{P} / \mathrm{F}$ & $\mathrm{P} / \mathrm{F}$ & $\mathrm{P} / \mathrm{F}$ & $\mathrm{P} / \mathrm{F}$ \\
\hline & distribuição & $\mathrm{d}$ & $f$ & $f$ & $\mathrm{~d}$ & $f$ \\
\hline & intensidade & $\mathrm{M}$ & $\mathrm{D}$ & $\mathrm{D}$ & M & M \\
\hline \multirow{3}{*}{ 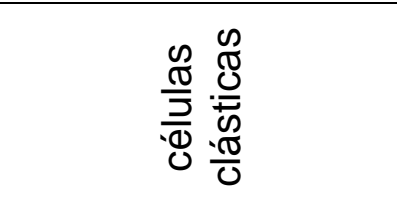 } & localização & $\mathrm{O} / \mathrm{C}$ & $\mathrm{O} / \mathrm{C}$ & $\mathrm{O} / \mathrm{C}$ & $\mathrm{O} / \mathrm{C}$ & $\mathrm{O}$ \\
\hline & intensidade & $\mathrm{M}$ & $\mathrm{D}$ & $\mathrm{D}$ & $\mathrm{D}$ & $\mathrm{D}$ \\
\hline & morfologia & $\mathrm{N}$ & $\mathrm{N}$ & $\mathrm{N}$ & $\mathrm{N}$ & $\mathrm{N}$ \\
\hline \multirow{2}{*}{$\begin{array}{l}\text { cavidade } \\
\text { cística }\end{array}$} & c/ epitélio de revestimento & $\mathrm{X}$ & $\mathrm{X}$ & $X$ & $\mathrm{X}$ & $\mathrm{X}$ \\
\hline & s/ epitélio de revestimento & - & - & - & $\mathrm{X}$ & $\mathrm{X}$ \\
\hline $\begin{array}{l}\text { restos epiteliais } \\
\text { de Malassez }\end{array}$ & localização & $\mathrm{F}$ & - & - & - & - \\
\hline \multirow{2}{*}{ tecido de granulação } & próximo ao ápice & $\mathrm{X}$ & - & - & - & - \\
\hline & periferia da lesão & $\mathrm{X}$ & $x$ & $\mathrm{X}$ & $\mathrm{X}$ & $\mathrm{X}$ \\
\hline
\end{tabular}

LEGENDA

-tipo celular

predominante

localização

distribuição

intensidade
$\mathrm{MN}=$ mononucleares

$\mathrm{PMN}=$ polimorfonucleares

$$
\mathrm{P}=\text { região periapical }
$$$$
\mathrm{F}=\text { região de furca }
$$

$$
f=\text { focal }
$$$$
\mathrm{d}=\text { difusa }
$$

$$
\mathrm{D}=\text { discreta }
$$$$
M=\text { moderada }
$$$$
\mathrm{I}=\text { intensa }
$$

-quanto às células clásticas:

$$
\begin{array}{ll}
\text { localização } & \mathrm{C}=\text { cemento } \\
& \mathrm{D}=\text { dentina }
\end{array}
$$

intensidade

$$
\mathrm{D}=\text { discreta }
$$$$
\mathrm{M}=\text { moderada }
$$$$
\mathrm{I}=\text { intensa }
$$

morfologia

$\mathrm{N}=$ normal

$\mathrm{A}=$ alterada

quanto aos restos epiteliais de Malassez: localização 


\section{Anexo 19}

Quadro 36 - Análise microscópica subjetiva quanto: ao infiltrado inflamatório, às células clásticas, à cavidade cística, aos restos epiteliais de Malassez e ao tecido de granulação, no período de 60 dias (grupo 6), realizado pelo examinador B.

\begin{tabular}{|c|c|c|c|c|c|c|}
\hline \multicolumn{7}{|c|}{ período experimental 60 dias - grupo 6} \\
\hline \multicolumn{2}{|c|}{ espécime } & 1 & 2 & 3 & 4 & 5 \\
\hline \multirow{4}{*}{ 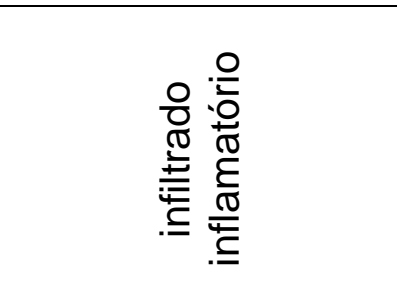 } & $\begin{array}{l}\text { tipo celular } \\
\text { predominante }\end{array}$ & PMN & PMN & MN & $\mathrm{MN}$ & PMN \\
\hline & localização & $\mathrm{P}$ & $\mathrm{P} / \mathrm{F}$ & $\mathrm{P} / \mathrm{F}$ & $\mathrm{P} / \mathrm{F}$ & $\mathrm{P} / \mathrm{F}$ \\
\hline & distribuição & $\mathrm{d}$ & $f$ & $f$ & $\mathrm{~d}$ & $f$ \\
\hline & intensidade & M & $\mathrm{D}$ & $\mathrm{D}$ & M & $\mathrm{M}$ \\
\hline \multirow{3}{*}{ 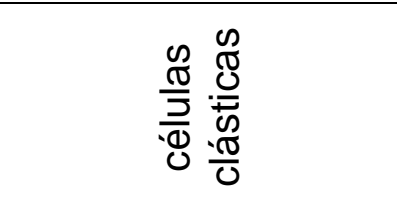 } & localização & $\mathrm{O} / \mathrm{C}$ & $\mathrm{O} / \mathrm{C}$ & $\mathrm{O} / \mathrm{C}$ & $\mathrm{O} / \mathrm{C}$ & $\mathrm{O}$ \\
\hline & intensidade & $\mathrm{M}$ & $\mathrm{D}$ & $\mathrm{D}$ & $\mathrm{D}$ & $\mathrm{D}$ \\
\hline & morfologia & $\mathrm{N}$ & $\mathrm{N}$ & $\mathrm{N}$ & $\mathrm{N}$ & $\mathrm{N}$ \\
\hline \multirow{2}{*}{$\begin{array}{l}\text { cavidade } \\
\text { cística }\end{array}$} & c/ epitélio de revestimento & $\mathrm{X}$ & $\mathrm{X}$ & $\mathrm{X}$ & $\mathrm{X}$ & $\mathrm{X}$ \\
\hline & s/ epitélio de revestimento & - & - & - & $\mathrm{X}$ & $\mathrm{X}$ \\
\hline $\begin{array}{l}\text { restos epiteliais } \\
\text { de Malassez }\end{array}$ & localização & $F$ & - & - & - & - \\
\hline \multirow{2}{*}{ tecido de granulação } & próximo ao ápice & $\mathrm{X}$ & - & - & - & - \\
\hline & periferia da lesão & $\mathrm{X}$ & $\mathrm{X}$ & $\mathrm{X}$ & $\mathrm{X}$ & $\mathrm{X}$ \\
\hline
\end{tabular}

LEGENDA

-tipo celular

predominante

localização

distribuição

intensidade
$\mathrm{MN}=$ mononucleares

PMN =polimorfonucleares

$$
\begin{aligned}
& P=\text { região periapical } \\
& F=\text { região de furca }
\end{aligned}
$$

$$
\begin{aligned}
& f=\text { focal } \\
& d=\text { difusa }
\end{aligned}
$$

$$
\mathrm{D}=\text { discreta }
$$$$
\mathrm{M}=\text { moderada }
$$$$
\text { I = intensa }
$$

-quanto às células clásticas:

$$
\begin{aligned}
& \mathrm{O}=\text { osso } \\
& \text { localização } \quad \mathrm{C}=\text { cemento } \\
& \mathrm{D}=\text { dentina } \\
& \mathrm{D}=\text { discreta } \\
& \text { intensidade } \quad \mathrm{M}=\text { moderada } \\
& \text { I = intensa } \\
& \text { morfologia } \quad \mathrm{N}=\text { normal } \\
& A=\text { alterada }
\end{aligned}
$$

-quanto aos restos epiteliais de Malassez: localização 


\section{Anexo 20}

Quadro 37: Análise microscópica subjetiva quanto ao infiltrado inflamatório, quanto às células clásticas, à cavidade cística, aos restos epiteliais de Malassez e ao tecido de granulação, no período de 90 dias (grupo 7), realizado pelo examinador $\mathrm{A}$.

\begin{tabular}{|c|c|c|c|c|c|c|}
\hline \multicolumn{7}{|c|}{ período experimental 90 dias - grupo 7} \\
\hline \multicolumn{2}{|r|}{ espécime } & 1 & 2 & 3 & 4 & 5 \\
\hline \multirow{4}{*}{ 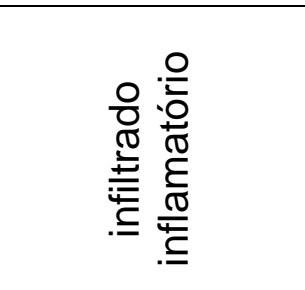 } & $\begin{array}{c}\text { tipo celular } \\
\text { predominante }\end{array}$ & MN & MN & PMN & $\mathrm{MN}$ & MN \\
\hline & localização & $\mathrm{F}$ & $\mathrm{P} / \mathrm{F}$ & $\mathrm{P} / \mathrm{F}$ & $\mathrm{P} / \mathrm{F}$ & $\mathrm{P} / \mathrm{F}$ \\
\hline & distribuição & $\mathrm{d}$ & d & $f$ & $\mathrm{~d}$ & d \\
\hline & intensidade & M & I & M & M & M \\
\hline \multirow{3}{*}{ 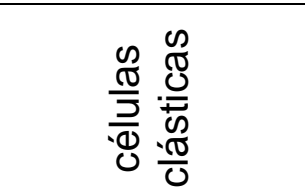 } & localização & $\mathrm{O}$ & $\mathrm{O}$ & $\mathrm{O} / \mathrm{C} / \mathrm{D}$ & $\mathrm{O} / \mathrm{C} / \mathrm{D}$ & $\mathrm{O} / \mathrm{C} / \mathrm{D}$ \\
\hline & intensidade & M & $\mathrm{D}$ & $M$ & $\mathrm{D}$ & $\mathrm{D}$ \\
\hline & morfologia & $\mathrm{N}$ & $\mathrm{N}$ & $\mathrm{N}$ & $\mathrm{N}$ & $N$ \\
\hline \multirow{2}{*}{$\begin{array}{c}\text { cavidade } \\
\text { cística }\end{array}$} & c/ epitélio de revestimento & $\mathrm{X}_{\mathrm{F}}$ & $X$ & - & $\mathrm{X}$ & $\mathrm{X}$ \\
\hline & s/ epitélio de revestimento & - & - & $X$ & - & $\mathrm{X}$ \\
\hline $\begin{array}{c}\text { restos epiteliais } \\
\text { de Malassez }\end{array}$ & localização & $\mathrm{P} / \mathrm{F}$ & $F$ & $\mathrm{~F}$ & $\mathrm{~F}$ & $\mathrm{~F}$ \\
\hline \multirow{2}{*}{$\begin{array}{l}\text { tecido de } \\
\text { granulação }\end{array}$} & próximo ao ápice & $\mathrm{X}$ & $\mathrm{X}$ & $\mathrm{X}$ & $\mathrm{X}$ & $\mathrm{X}$ \\
\hline & periferia da lesão & $\mathrm{X}$ & $\mathrm{X}$ & $\bar{X}$ & $\bar{X}$ & $\mathrm{X}$ \\
\hline
\end{tabular}

\section{LEGENDA}

-tipo celular

predominante

localização

distribuição

intensidade
$\mathrm{MN}=$ mononucleares

PMN =polimorfonucleares

$$
\mathrm{P}=\text { região periapical }
$$$$
\mathrm{F}=\text { região de furca }
$$

$$
\begin{aligned}
& f=\text { focal } \\
& d=\text { difusa } \\
& D=\text { discreta } \\
& M=\text { moderada } \\
& I=\text { intensa }
\end{aligned}
$$

quanto aos restos epiteliais de Malassez:

$$
\mathrm{P}=\text { região periapical }
$$$$
\mathrm{F}=\text { região de furca }
$$

-quanto às células clásticas:

$\mathrm{O}=$ osso

localização

$\mathrm{C}=$ cemento

$\mathrm{D}=$ dentina

intensidade

$\mathrm{D}=$ discreta

$\mathrm{M}=$ moderada

$\mathrm{I}=$ intensa

morfologia

$\mathrm{N}=$ normal

$A=$ alterada Iocalização 


\section{Anexo 21}

Quadro 38 - Análise microscópica subjetiva quanto: ao infiltrado inflamatório, às células clásticas, à cavidade cística, aos restos epiteliais de Malassez e ao tecido de granulação, no período de 90 dias (grupo 7), realizado pelo examinador B.

\begin{tabular}{|c|c|c|c|c|c|c|}
\hline \multicolumn{7}{|c|}{ período experimental 90 dias - grupo 7} \\
\hline \multirow{5}{*}{ 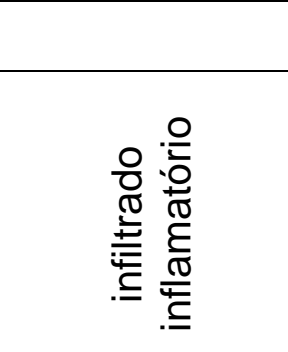 } & espécime & 1 & 2 & 3 & 4 & 5 \\
\hline & $\begin{array}{c}\text { tipo celular } \\
\text { predominante }\end{array}$ & MN & MN & PMN & MN & MN \\
\hline & localização & $\mathrm{F}$ & $\mathrm{P} / \mathrm{F}$ & P/F & $\mathrm{P} / \mathrm{F}$ & $\mathrm{P} / \mathrm{F}$ \\
\hline & distribuição & $\mathrm{d}$ & $\mathrm{d}$ & $f$ & $\mathrm{~d}$ & $\mathrm{~d}$ \\
\hline & intensidade & M & 1 & M & M & M \\
\hline \multirow{3}{*}{ 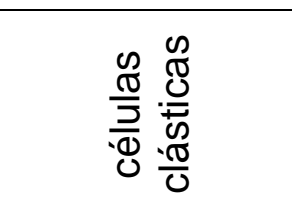 } & localização & $\mathrm{O}$ & $\mathrm{O}$ & $\mathrm{O} / \mathrm{C} / \mathrm{D}$ & $\mathrm{O} / \mathrm{C} / \mathrm{D}$ & $\mathrm{O} / \mathrm{C} / \mathrm{D}$ \\
\hline & intensidade & M & $\mathrm{D}$ & M & $\mathrm{D}$ & $\mathrm{D}$ \\
\hline & morfologia & $\mathrm{N}$ & $\mathrm{N}$ & $\mathrm{N}$ & $\mathrm{N}$ & $\mathrm{N}$ \\
\hline \multirow{2}{*}{$\begin{array}{l}\text { cavidade } \\
\text { cística }\end{array}$} & c/ epitélio de revestimento & $\mathrm{X}_{\mathrm{F}}$ & $\mathrm{X}$ & - & $\mathrm{X}$ & $\mathrm{X}$ \\
\hline & s/ epitélio de revestimento & - & - & $\mathrm{X}$ & - & $\mathrm{X}$ \\
\hline $\begin{array}{l}\text { restos epiteliais } \\
\text { de Malassez }\end{array}$ & localização & $\mathrm{P} / \mathrm{F}$ & $F$ & $F$ & $F$ & $\mathrm{~F}$ \\
\hline \multirow{2}{*}{$\begin{array}{c}\text { tecido de } \\
\text { granulação }\end{array}$} & próximo ao ápice & $\mathrm{X}$ & $\mathrm{X}$ & $\mathrm{X}$ & $\mathrm{X}$ & $\mathrm{X}$ \\
\hline & periferia da lesão & $\mathrm{X}$ & $\mathrm{X}$ & $\mathrm{X}$ & $\mathrm{X}$ & $\mathrm{X}$ \\
\hline
\end{tabular}

\section{LEGENDA}

-tipo celular

predominante

localização

distribuição

intensidade
$\mathrm{MN}=$ mononucleares

$\mathrm{PMN}=$ polimorfonucleares

\section{$\mathrm{P}=$ região periapical}

$\mathrm{F}=$ região de furca

$$
\begin{aligned}
& f=\text { focal } \\
& d=\text { difusa } \\
& D=\text { discreta } \\
& M=\text { moderada } \\
& I=\text { intensa }
\end{aligned}
$$

-quanto aos restos epiteliais de Malassez:

$$
\mathrm{P}=\text { região periapical }
$$$$
\mathrm{F}=\text { região de furca }
$$

\section{-quanto às células clásticas:}

$$
\begin{array}{ll} 
& O=\text { osso } \\
\text { localização } & C=\text { cemento } \\
& D=\text { dentina }
\end{array}
$$

intensidade

$$
D=\text { discreta }
$$$$
\mathrm{M}=\text { moderada }
$$$$
\mathrm{I}=\text { intensa }
$$

morfologia

$\mathrm{N}=$ normal

$A=$ alterada 


\section{Anexo 22}

Quadro 39: Análise microscópica subjetiva quanto: ao infiltrado inflamatório, às células clásticas, à cavidade cística, aos restos epiteliais de Malassez e ao tecido de granulação, no período de 120 dias (grupo 8), realizado pelo examinador A.

\begin{tabular}{|c|c|c|c|c|c|c|}
\hline \multicolumn{7}{|c|}{ período experimental 120 dias - grupo 8} \\
\hline \multicolumn{2}{|c|}{ espécime } & 1 & 2 & 3 & 4 & 5 \\
\hline \multirow{4}{*}{ 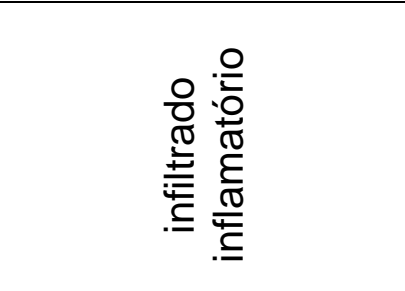 } & $\begin{array}{l}\text { tipo celular } \\
\text { predominante }\end{array}$ & MN & PMN & MN & $\mathrm{MN}$ & $\mathrm{MN}$ \\
\hline & localização & $\mathrm{P} / \mathrm{F}$ & $\mathrm{F}$ & $P$ & $F$ & $P$ \\
\hline & distribuição & $\mathrm{d}$ & $\mathrm{d}$ & d & $\mathrm{d}$ & $\mathrm{d}$ \\
\hline & intensidade & I & I & $M$ & M & $M$ \\
\hline \multirow{3}{*}{ 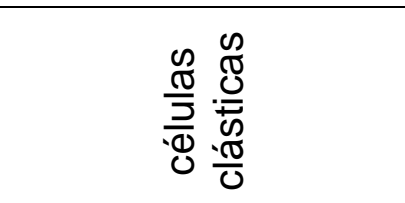 } & localização & $\mathrm{O} / \mathrm{C} / \mathrm{D}$ & $\mathrm{O} / \mathrm{C}$ & $\mathrm{O} / \mathrm{C}$ & $\mathrm{O} / \mathrm{C}$ & $\mathrm{O} / \mathrm{C}$ \\
\hline & intensidade & $\mathrm{D}$ & $\mathrm{D}$ & $\mathrm{D}$ & $\mathrm{D}$ & $\mathrm{M}$ \\
\hline & morfologia & $\mathrm{N}$ & $\mathrm{N}$ & $\mathrm{N}$ & $\mathrm{N}$ & $\mathrm{N}$ \\
\hline \multirow{2}{*}{$\begin{array}{c}\text { cavidade } \\
\text { cística }\end{array}$} & c/ epitélio de revestimento & $\mathrm{X}$ & $\mathrm{X}$ & $\mathrm{X}$ & $X$ & $\mathrm{X}$ \\
\hline & s/ epitélio de revestimento & - & - & $\mathrm{X}$ & $X$ & $X$ \\
\hline $\begin{array}{c}\text { restos epiteliais } \\
\text { de Malassez }\end{array}$ & localização & - & $P$ & $\mathrm{~F}$ & - & - \\
\hline \multirow{2}{*}{ tecido de granulação } & próximo ao ápice & $X$ & $\mathrm{X}$ & $X$ & $\mathrm{X}$ & $\mathrm{X}$ \\
\hline & periferia da lesão & $X$ & $X$ & $\mathrm{X}$ & $\mathrm{X}$ & $\mathrm{X}$ \\
\hline
\end{tabular}

LEGENDA

-tipo celular

predominante

localização

distribuição

intensidade
$\mathrm{MN}=$ mononucleares

PMN =polimorfonucleares

$P=$ região periapical
$F=$ região de furca

$$
\begin{aligned}
& f=\text { focal } \\
& d=\text { difusa } \\
& D=\text { discreta } \\
& M=\text { moderada } \\
& I=\text { intensa }
\end{aligned}
$$

quanto aos restos epiteliais de Malassez: localização -quanto às células clásticas:

$$
\text { localização } \quad \begin{array}{ll}
C=\text { cemento } \\
D
\end{array}
$$

$$
\begin{array}{cl}
\text { intensidade } & D=\text { discreta } \\
& M=\text { moderada } \\
& I=\text { intensa } \\
\text { morfologia } & N=\text { normal } \\
& A=\text { alterada }
\end{array}
$$




\section{Anexo 23}

Quadro 40 - Análise microscópica subjetiva quanto: ao infiltrado inflamatório, às células clásticas, à cavidade cística, aos restos epiteliais de Malassez e ao tecido de granulação, no período de 120 dias (grupo 8), realizado pelo examinador B.

\begin{tabular}{|c|c|c|c|c|c|c|}
\hline \multicolumn{7}{|c|}{ período experimental 120 dias - grupo 8} \\
\hline \multicolumn{2}{|c|}{ espécime } & 1 & 2 & 3 & 4 & 5 \\
\hline \multirow{4}{*}{ 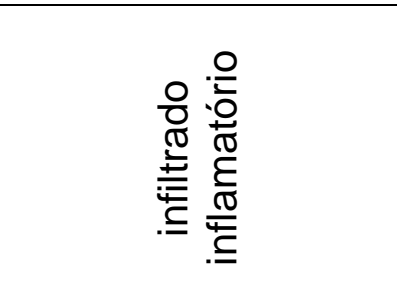 } & $\begin{array}{l}\text { tipo celular } \\
\text { predominante }\end{array}$ & $\mathrm{MN}$ & PMN & $\mathrm{MN}$ & MN & MN \\
\hline & localização & $\mathrm{P} / \mathrm{F}$ & $\mathrm{F}$ & $\mathrm{P}$ & $\mathrm{F}$ & $\mathrm{P}$ \\
\hline & distribuição & $\mathrm{d}$ & $\mathrm{d}$ & $\mathrm{d}$ & $\mathrm{d}$ & d \\
\hline & intensidade & I & I & M & M & I \\
\hline \multirow{3}{*}{ 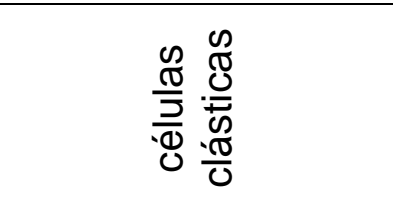 } & localização & $\mathrm{O} / \mathrm{C} / \mathrm{D}$ & $\mathrm{O} / \mathrm{C}$ & $\mathrm{O} / \mathrm{C}$ & $\mathrm{O} / \mathrm{C}$ & $\mathrm{O} / \mathrm{C}$ \\
\hline & intensidade & $\mathrm{D}$ & $\mathrm{D}$ & $\mathrm{D}$ & $\mathrm{M}$ & $\mathrm{M}$ \\
\hline & morfologia & $\mathrm{N}$ & $\mathrm{N}$ & $\mathrm{N}$ & $\mathrm{N}$ & $\mathrm{N}$ \\
\hline \multirow{2}{*}{$\begin{array}{l}\text { cavidade } \\
\text { cística }\end{array}$} & c/ epitélio de revestimento & $\mathrm{X}$ & $\mathrm{X}$ & $\mathrm{x}$ & $\mathrm{X}$ & $\mathrm{X}$ \\
\hline & s/ epitélio de revestimento & - & - & $\mathrm{X}$ & $X$ & $\mathrm{X}$ \\
\hline $\begin{array}{c}\text { restos epiteliais } \\
\text { de Malassez }\end{array}$ & localização & - & $P$ & $\mathrm{~F}$ & - & - \\
\hline \multirow{2}{*}{ tecido de granulação } & próximo ao ápice & $\mathrm{X}$ & $\mathrm{X}$ & $\mathrm{X}$ & $\mathrm{X}$ & $\mathrm{X}$ \\
\hline & periferia da lesão & $\mathrm{X}$ & $\mathrm{X}$ & $\mathrm{X}$ & $\mathrm{X}$ & $\mathrm{X}$ \\
\hline
\end{tabular}

\section{LEGENDA}

-tipo celular

predominante

localização

distribuição

intensidade
$\mathrm{MN}=$ mononucleares

PMN =polimorfonucleares

$$
\mathrm{P}=\text { região periapical }
$$$$
\mathrm{F}=\text { região de furca }
$$

$$
\begin{aligned}
& f=\text { focal } \\
& d=\text { difusa } \\
& D=\text { discreta } \\
& M=\text { moderada } \\
& I=\text { intensa }
\end{aligned}
$$

-quanto aos restos epiteliais de Malassez: localização

\section{-quanto às células clásticas:}

$$
\begin{array}{ll}
\text { localização } & C=\text { cemento } \\
& D=\text { dentina }
\end{array}
$$

intensidade

$\mathrm{D}=$ discreta

$\mathrm{M}=$ moderada

I = intensa

morfologia

$\mathrm{N}=$ normal

$\mathrm{A}=$ alterada 


\section{Anexo 24}

Quadro 41: Análise microscópica subjetiva quanto ao infiltrado inflamatório, quanto às células clásticas, à cavidade cística, aos restos epiteliais de Malassez e ao tecido de granulação, no período de 180 dias (grupo 9), realizado pelo examinador $A$.

\begin{tabular}{|c|c|c|c|c|c|c|}
\hline \multicolumn{7}{|c|}{ período experimental 180 dias - grupo 9} \\
\hline \multicolumn{2}{|r|}{ espécime } & 1 & 2 & 3 & 4 & 5 \\
\hline \multirow{4}{*}{ 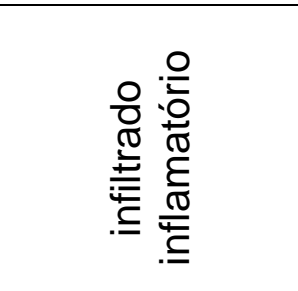 } & $\begin{array}{l}\text { tipo celular } \\
\text { predominante }\end{array}$ & PMN & $\mathrm{MN}$ & $\mathrm{MN}$ & MN & MN \\
\hline & localização & $P$ & $\mathrm{P}$ & $P$ & $\mathrm{P} / \mathrm{F}$ & $P$ \\
\hline & distribuição & d & d & d & $\mathrm{d}$ & d \\
\hline & intensidade & $\mathrm{D}$ & $\mathrm{D}$ & $\mathrm{D}$ & M & M \\
\hline \multirow{3}{*}{ 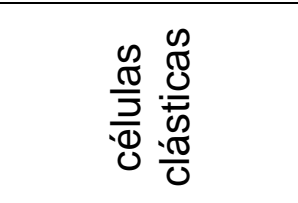 } & localização & $\mathrm{O} / \mathrm{C} / \mathrm{D}$ & $\mathrm{O} / \mathrm{C} / \mathrm{D}$ & $\mathrm{O} / \mathrm{C} / \mathrm{D}$ & $\mathrm{O} / \mathrm{C} / \mathrm{D}$ & $\mathrm{O} / \mathrm{C} / \mathrm{D}$ \\
\hline & intensidade & $\mathrm{M}$ & $\mathrm{M}$ & $\mathrm{M}$ & $\mathrm{M}$ & $\mathrm{D}$ \\
\hline & morfologia & $\mathrm{N}$ & $\mathrm{N}$ & $\mathrm{N}$ & $\mathrm{N}$ & $\mathrm{N}$ \\
\hline \multirow{2}{*}{$\begin{array}{l}\text { cavidade } \\
\text { cística }\end{array}$} & c/ epitélio de revestimento & $\mathrm{X}$ & - & - & $\mathrm{X}$ & $\mathrm{X}$ \\
\hline & s/ epitélio de revestimento & - & - & - & - & - \\
\hline $\begin{array}{c}\text { restos epiteliais } \\
\text { de Malassez }\end{array}$ & localização & $F$ & $P$ & - & $P$ & $\mathrm{~F}$ \\
\hline \multirow{2}{*}{$\begin{array}{c}\text { tecido de } \\
\text { granulação }\end{array}$} & próximo ao ápice & $\bar{X}$ & - & - & $\mathrm{X}$ & $\mathrm{X}$ \\
\hline & periferia da lesão & - & $\mathrm{X}$ & $\mathrm{X}$ & - & $\mathrm{X}$ \\
\hline
\end{tabular}

LEGENDA

-tipo celular

predominante

localização

distribuição

intensidade
$\mathrm{MN}=$ mononucleares

PMN =polimorfonucleares

$$
\mathrm{P}=\text { região periapical }
$$$$
\mathrm{F}=\text { região de furca }
$$

$$
\begin{aligned}
& f=\text { focal } \\
& d=\text { difusa } \\
& D=\text { discreta } \\
& M=\text { moderada } \\
& I=\text { intensa }
\end{aligned}
$$

quanto aos restos epiteliais de Malassez: localização -quanto às células clásticas:

\begin{tabular}{ll}
\hline \multirow{2}{*}{ localização } & $\mathrm{O}=$ osso \\
& $\mathrm{C}=$ cemento \\
& $\mathrm{D}=$ dentina
\end{tabular}

intensidade

$\mathrm{D}=$ discreta

$\mathrm{M}=$ moderada

$\mathrm{I}$ = intensa

morfologia

$\mathrm{N}=$ normal

$\mathrm{A}=$ alterada 


\section{Anexo 25}

Quadro 42 - Análise microscópica subjetiva quanto: ao infiltrado inflamatório, às células clásticas, à cavidade cística, aos restos epiteliais de Malassez e ao tecido de granulação, no período de 180 dias (grupo 9), realizado pelo examinador B.

\begin{tabular}{|c|c|c|c|c|c|c|}
\hline \multicolumn{7}{|c|}{ período experimental 180 dias - grupo 9} \\
\hline \multicolumn{2}{|c|}{ espécime } & 1 & 2 & 3 & 4 & 5 \\
\hline \multirow{4}{*}{ 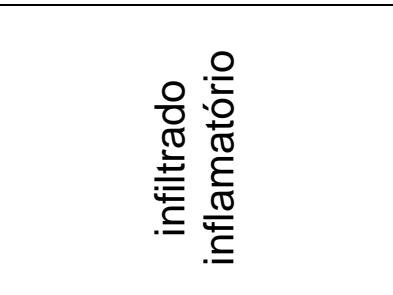 } & $\begin{array}{l}\text { tipo celular } \\
\text { predominante }\end{array}$ & MN & PMN & MN & MN & $\mathrm{MN}$ \\
\hline & localização & $\mathrm{P} / \mathrm{F}$ & $F$ & $\mathrm{P}$ & $F$ & $\mathrm{P}$ \\
\hline & distribuição & d & d & d & d & d \\
\hline & intensidade & 1 & $\mathrm{I}$ & M & M & $\mathrm{I}$ \\
\hline \multirow{3}{*}{ 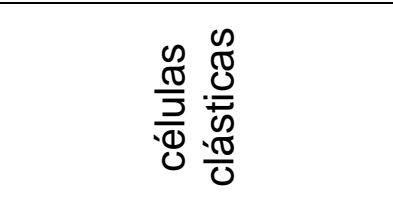 } & localização & $\mathrm{O} / \mathrm{C} / \mathrm{D}$ & $\mathrm{O} / \mathrm{C}$ & $\mathrm{O} / \mathrm{C}$ & $\mathrm{O} / \mathrm{C}$ & $\mathrm{O} / \mathrm{C}$ \\
\hline & intensidade & $\mathrm{D}$ & $\mathrm{D}$ & $\mathrm{D}$ & $\mathrm{M}$ & $\mathrm{M}$ \\
\hline & morfologia & $\mathrm{N}$ & $\mathrm{N}$ & $\mathrm{N}$ & $\mathrm{N}$ & $\mathrm{N}$ \\
\hline \multirow{2}{*}{$\begin{array}{l}\text { cavidade } \\
\text { cística }\end{array}$} & c/ epitélio de revestimento & $X$ & $\mathrm{X}$ & $X$ & $\mathrm{X}$ & $\mathrm{X}$ \\
\hline & s/ epitélio de revestimento & - & - & $X$ & $X$ & $X$ \\
\hline $\begin{array}{l}\text { restos epiteliais } \\
\text { de Malassez }\end{array}$ & localização & - & $P$ & $\mathrm{~F}$ & - & - \\
\hline \multirow{2}{*}{ tecido de granulação } & próximo ao ápice & $\mathrm{X}$ & $\mathrm{X}$ & $X$ & $\mathrm{X}$ & $\mathrm{X}$ \\
\hline & periferia da lesão & $X$ & $\mathrm{X}$ & $X$ & $\mathrm{X}$ & $\mathrm{X}$ \\
\hline
\end{tabular}

\section{LEGENDA}

-tipo celular

predominante

localização

distribuição

intensidade
$\mathrm{MN}=$ mononucleares

$\mathrm{PMN}=$ polimorfonucleares

$$
\begin{aligned}
& P=\text { região periapical } \\
& F=\text { região de furca }
\end{aligned}
$$

$$
\begin{aligned}
& f=\text { focal } \\
& d=\text { difusa }
\end{aligned}
$$$$
\mathrm{D}=\text { discreta }
$$$$
\mathrm{M}=\text { moderada }
$$$$
\mathrm{I}=\text { intensa }
$$

-quanto às células clásticas:

$$
\begin{aligned}
& \mathrm{O}=\text { osso } \\
& \mathrm{C}=\text { cemento } \\
& \mathrm{D}=\text { dentina } \\
& \mathrm{D}=\text { discreta } \\
& \mathrm{M}=\text { moderada } \\
& \text { I = intensa } \\
& \text { morfologia } \quad \mathrm{N}=\text { normal } \\
& A=\text { alterada }
\end{aligned}
$$

-quanto aos restos epiteliais de Malassez: localização 


\section{7 - REFERÊNCIAS BIBLIOGRÁFICAS ${ }^{*}$}

1. AKAMINE, A.; ANAN; HAMACHI; MAEDA. A histochemical study of the behavior of macrophagues during experimental apical periodontitis in rat. J Endod, U.S.A., v.20, n.10, p.474-78, Oct.1994b.

2. ANALOUI, M.; BUCKWALTER, K. Digital radiographic imagem archival, retrieval, and management. Dent Clin N Amer, v.44, n.2, p.339-58, Apr. 2000.

3. BALTO, K.; WHITE, R.; MUELLER, R.; STASHENKO, P. A mouse model of inflammatory root resorption induced by pulpal infection. J Endod, v.93, n.4, p.461-8, Apr. 2002.

4. BOHNE, W. Light and ultrastructural studies on human chronic periapical lesions. J Oral Pathol Med, v.19, p.215-20, 1990.

5. CALISKAN, M. K. Prognosis of large cyst-like periapical lesions following nonsurgical root canal treatment: a clinical review. Int Endod J, v.37, n.6, p.408-16, Jun. 2004.

\footnotetext{
* Normas recomendadas para o uso no âmbito da Universidade de São Paulo, com base no documento "Referências Bibliográficas: exemplos", emanados do Conselho Supervisor do Sistema Integrado de Bibliotecas da USP, em reunião de 20 de setembro de 1990.
} 
6. CAPELOZZA, A. L. A. Estudo comparativo de algumas lesões do periápice através da imagem radiográfica convencional e imagem digital indireta utilizando o Programa Adobe Photoshop 5.0. Bauru, 2001. 127p. Tese (Livre Docência) Faculdade de Odontologia de Bauru, Universidade de São Paulo.

7. CASATI-AlVARES, L.; MARZOLA, C.; FREITAS, J. A. S. Cisto ou granulomas apicais _ Aparência radiográfica versus histo-patológica. Estomatologia e Cultura, v.5, n.1, p.22-7, Jan./June 1971.

8. COHEN, S.; BURNS, R. C. Pathways of the pulp. 6 ed. St. Louis: Mosby, 1994.

9. CONSOLARO, A.; RIBEIRO, F. C. Periapicopatias: Etiopatogenia e Interrelações dos aspectos clínicos, radiográficos e microscópicos e suas implicações terapêuticas. In: Endodontia: Tratamento de canais radiculares. 3ed. São Paulo, Panamericana, 1998, Cap.5, p.77-102.

10. COROTTI, M. V. Avaliação imuno-histoquímica das MMPs-2 e $\mathbf{- 9}$ na evolução de lesões periapicais induzidas em dentes molares de ratos. Bauru, 2005. 63p. Dissertação (Mestrado em Biologia Oral) Faculdade de Odontologia de Bauru, Universidade de São Paulo. 
11. DAMANTE, J. H.; CARVALHO, P. V. Contribuição à interpretação radiográfica das lesões ósseas produzidas experimentalmente em mandíbulas humana secas(Parte I). Rev Odont USP, v.2, n.3, p.131-8, Jul.-Set. 1988.

12. DANIEL, R. L. D. P. Análises radiográfica e microscópica do processo de reparo de lesões periapicais após o emprego de medicação intracanal em dentes de ratos. São Paulo, 2001. 114p. Tese (Doutorado em Endodontia) Faculdade de Odontologia de São Paulo, Universidade de São Paulo.

13. DIETZ, V. H. Intracutaneous tests using filtrates prepared from pathologic pulps of human teeth, with special reference to rheumatoid arthritis. Oral Surg, v.5, p.59-73, 1952.

14. DUNN, S. N.; KANTOR, M. L. Digital radiology facts and fictions. J Am Dent Assoc, v.124, n., p.39-47, 1993.

15. EBIHARA, A.; YOSHIOKA, T.; SUDA, H. Garre's osteomyelitis managed by root canal treatment of a mandibular second molar: incorporation of computed tomography with 3D reconstruction in the diagnosis and monitoring of the disease. Int Endod J, v.38, n.4, p.255-61, Apr.2005. 
16. EURASQUIM, J.; MURUZABAL, M. A. A method for root canal treatment in the molar of rat. Oral Surg, v.24, n.4, p.540-6, Oct. 1967.

17. FAWZI, M. I.; SHKLAR, G.; KRAKOW, A. A. The effect of radiation on the response of dental pulp to operative and endodontic procedures: An experimental study. Oral Surg Oral Med Oral Pathol, v.59, n.4, p.40513, 1985.

18. FERLINI FILHO, J. Estudo radiográfico e microscópico das reabsorções radiculares na presença de periodontites apicais crônicas (microscopia óptica e eletrônica de varredura). Bauru, 1999. Tese (Doutorado em Endodontia) Faculdade de Odontologia de Bauru, Universidade de São Paulo.

19. GIRSCH, W. J.; MATTESON, S. R.; MCKEE, M. N. An evaluation of Kodak Ektaspeed periapical film for use in endodontics. J Endod, v.9, p.282-8, 1983.

20. GOGA, R.; CHANDLER, N. P.; LOVE, R. M. Clarity and diagnostic quality of digitized conventional intraoral radiographs. Dentomaxillofac Radiol, v.33, n.2, p.103-7, Mar. 2004.

21. GRÖNDAHL, H-G. Digital radiology in dental diagnosis: a critical view. Dentomaxillof, v.21, p.198-202, Nov.1992. 
22. GUNERI, P.; AKDENIZ, B.; G. Fraudulent management of digital endodontic images. Int Endod J, v.37, n.3, p.214-20, Mar. 2004.

23. HONG, C.Y.; LIN, S. K.; KOK, S. H.; CHENG, S. J.; LEE, M. S.; WANG, T. M.; CHEN, C. S.; LIN, L. D.; WANG, J. S. The role of lipopolysaccharide in infectious bone resorption of periapical lesion. J Oral Pathol Med, v.33, n.3, p.162-9, Mar. 2004.

24. HOLTZMANN, D.J. et al. Storage-phosphor computer radiography versus film radiography in detection of pathologic perriradicular loss in cadavers. Oral Surg, v.86, n.11, p.90-7, 1998.

25. IMAGELAB - Sistema de processamento e Análise de imagem. 85p.

26. JOHANNESSEN, L. B. Presence of enamel-covered cuspds in rat molar. Arch Oral Biol, p.61-2, 1961.

27. JOHANSEN, J. R. Incorporation of tritiated thymidine by the epithelial rests. Acta Odontol Scand, v.28, n.4, p.463-70, Nov.1970.

28. KAKEHASHI, S.; STANLEY, H. R.; FITZGERALD, R. J. The effects of surgical exposures of dental pulps in germ-free and conventional laboratory rats. Oral Surg, v.20, n.3, p.340-9, Sept. 1965. 
29. KANEKO, T.; OKIJI, T.; KAN, L.; SUDA, H.; TAKAGI, M. An immunoelectron-microscopic study of class II major histocompatibility complex molecule-expressing macrophages and dendritic cells in experimental rat periapical lesions. Arch Oral Biology, v.46, p.713-20, 2001.

30. KAWAHARA, T.; MURAKAMI, S.; NOIRI, Y.; EHARA, A.; TAKEMURA, N.; FURUKAWA, S.; EBISU, S. Effects of cyclosporin-A-induced immunosuppression on periapical lesions in rats. J Dent Res, v83, n.9, p.683-7, Sep. 2004

31. KAWASHIMA, N.; OKIJI, T.; KOSAKA, T.; SUDA, H. Kinetics of macrophages and lymphoid cells during the development of experimentally induced periapical lesions in rat molars: a quantitative immunohistochemical study. J Endod, v.22, n.6, p.311-16, June 1996.

32. KHOCHT, A.; JANAL, M.; CHANG, K. Comparison of direct digital and convencional intraoral radiographs in detecting alveolar bone loss. J Am Dent Assoc, v.134, n.11, p.1468-75, Nov. 2003.

33. KLEIER, D. J.; BENNER, S. J.; AVERBACH, R. E. Two dental x-ray films compared for rater preference using endodontic views. Oral Surg Oral Med Oral Pathol, v.59, n.2, p. 201-5, Feb. 1985. 
34. KRONFELD, R. The biology of cementum. J Am Dent Assoc, v.25, n.9, p. 451-61, Sept. 1938.

35. KUBOTA, Y. et al. Discrimination of ameloblastoma from odontogenic keratocysts by citokine levels and gelatinase species opf the intracystic fluids . J Oral Pathol Med, v.30, n.7, p. 421-7, Aug. 2001.

36. LIN, S-K. et al. Immunolocalization of macrophages and transforming growth factor- $\beta_{1}$ in induced rat periapical lesions. J Endod, v.26, n.6, p.335-40, June 2000.

37. LOPES, H. P.; SIQUEIRA, Jr. Endodontia, biologia e técnica. Rio de Janeiro, Medsi, 1999.

38. LOVSCHALL, H.; FEJERSKOV, K.; JOSEPHSEN, K. Age-related and sitespecific changes in the pulpodentinal morphology of rat molars. Arch Oral Biology, v.47, p. 361-7, 2002.

39. MARTON, I. J.; KISS, C. Protective and destructive immune reactions in apical periodontitis. Oral Microbiol Immunol, v.15, n.3, p.139-50, Jun.2000. 
40. MISTAK, E. J.; LOUSHINE, R. J.; PRIMACK, P. D.; WEST, L. A.; RUNYAN, D. A. Interpretation of periapical lesions comparing conventional, direct digital, and telephonically transmitted radiographic images. J Endod, v.24, n.4, p. 262-6, April 1998.

41. MOSKOVITZ, M.; SAMMARA, E.; HOLAN, G. Success rate of root canal treatment in primary molars. J Dent, v.33, n.1, p.41-7, Jan. 2005.

42. MOUYEN, F.; BENZ, C.; SONNABEND, E.; LODTER, J. P. Presentation and physical evaluation of Radiovisiography . Oral Surg Oral Med Oral Pathol , v.68, n.2, p.238-42, Aug.1989.

43. NAIR, P. N. Pathogenesis of apical periodontitis and the causes of endodontic failures. Crit Rev Oral Biol Med, v.15, n.6, p.348-81, Nov. 2004.

44. NAIR, P. N. R.; PAJAROLA, G.; SCHROEDER, H. E. Types and incidnce of human periapical lesions obtained with extracted teeth. Oral Surg Oral Med Oral Pathol Oral Radiol Endod, v.81, n.1, p.93-102, Jan.1996.

45. NISHIYAMA, C. K. Comparação de três diferentes técnicas de instrumentação mecânica rotatória com limas de níquel titânio. Analise da variação do ângulo de curvatura, deslocamento do 
centro do instrumento e alteração na área da secção transversal do canal radicular: (estudo in vitro). Araraquara, 2001. 162 p. Tese (Doutorado em Endodontia) Faculdade de Odontologia de Araraquara, Universidade Estadual Paulista.

46. PEREIRA, F. A. Estudo histopatológico e radiográfico de lesões periapicais. Natal, 1983. Dissertação (Mestrado em Patologia Oral) Faculdade de Odontologia da Universidade Federal do Rio Grande do Norte.

47. PORTER, G. The norway rat. In: The UFAN handbook on the care and manegement of laboratory animals. $3^{\text {aed. }}$ 1967. Cap.22, p.353-90.

48. QU, Z. et al. Mast cells are a major source of basic fibroblastic growth factor in chronic inflammation and cutaneous hemangioma. Am J Pathol, v.147, n.3, p.564-73, 1995.

49. RICHARDS , A. G.; COLQUITT, W. N. Reduction in dental x-ray exposures during the past 60 years. J Am Dent Assoc, v.103, n.x, p. 713-8, Nov.1981.

50. RODINI, C. O. Doença periodontal inflamatória induzida por ligadura: Caracterização microscópica e estudo da presença de mastócitos e das enzimas óxido nítrico sintase induzível (iNOS) e 
metaloproteinase -2 e -9. Bauru, 2005. 149p. Dissertação (Mestrado em Patologia Bucal) Faculdade de Odontologia de Bauru, Universidade de São Paulo.

51. RODINI, C. O.; BATISTA, A. C.; LARA, V. S. Comparative immunohistochemical study of the presence of mast cells in apical granulomas and periapical cysts: Possible role of mast cells in the course of human peripical lesions. Oral Surg Oral Med Oral Pathol, v.97, n.1, p. 59-63, Jan. 2004.

52. SALLES C. L. F. Avaliação dos efeitos do glutaraldeido sobre os tecidos pulpares e periapicais após pulpotomias em molares de ratos: estudo microscópico. Bauru, 1989. 92p. Dissertação (Mestrado em Endodontia) Faculdade de Odontologia de Bauru, Universidade de São Paulo.

53. SCHOUR, I.; MASSLER, M. The teeth. In: The rat in laboratory investigation. 2ed. New York: Hafner, 1949, p.104-65.

54. SHAFER, W.G.; HINE, M.K.; LEVY, B.M. A textbook of oral pathology. 4ed. Philadelphia, W.B. Saunders, 1983. 
55. SHIN, S. J.; LEE, J. I.; BAEK, S. H.; LIM, S. S. Tissue levels of matrix metaloproteinases in puls and periapical lesions. J Endod, v.28, n.4, p.313-5, Apr. 2002.

56. SOUZA, M. A. L A Morphometric and histological study on the development and eruption on the rat mandibular first molar tooth. Newcastle, 1999. Dissertação (Mestrado em Ciências) - University of Newcastle upon Tyne .

57. STASHENKO, P.; WANG, C-Y.; TANI-ISHII, N.; YU, S. M. Pathogenesis of induced rat periapical lesions. Oral Surg Oral Med Oral Pathol, v.78, n.4, p.494-502, Oct. 1994.

58. STASHENKO, P.; YU, S. M.; WANG, C-Y. Kinects of immune cell and bone resorptive response to endodontic infections. J Endod, v.18, n.9, p.4226, Sep. 1992.

59. STASHENKO, P.; YU, S. M. T Helper and T Suppressor cell reversal during the development of induced rat periapical lesions. J Dent Res, v.68, n.5, p.830-4, May 1989.

60. SULLIVAN, J. E.; DI FIORE, P. M.; KOERBER, A. RadioVisiography in the detection of periapical lesions. J Endod, v.26, n.1, p.32-5, Jan. 2000. 
61. TAGGER, M.; MASSLER, M. Periapical tissue reactions after pulp exposure in rat molars. Oral Surg, v.39, n.2, p.304-17, Feb.1975.

62. TANI-ISHII, N.; WANG, C-Y.; STASHENKO, P. Immunolocalization of boneresorptive cytokines in rat pulp and periapical lesions following surgical pulp exposure. Oral Microbiol Immunol, v.10, p.213-9, 1995.

63. TEN CATE, A. R. Repair and regeneration of dental tissue. In: Oral histology: development, structure and function. 4ed. St. Louis, Mosby, 1994. Cap. 20, p.456-468.

64. TEXEIRA, F. B.; GOMES, B. P. F. A.; FERRAZ, C. C. R.; SOUZA-FILHO, J.; ZAIA, A. A. Radiographic analysis of the development of periapical lesions in normal rats, sialoadenectomized rats ad sialonectomizedimmunosupressed rats. Endod Dent Traumatol, v.16, p.154-7, 2000.

65. THARP, M. D. The interaction between mast cells and endothelial cells. J Invest Dermatol, v.92, n.2(Suppl), p.107S-112S, 1989.

66. TORABINEJAD, M.; BAKLAND L,K. Immunopathogenesis of periapical lesions. Oral Surg, v.46, n.5, p.685-95, Nov. 1978. 
67. TORABINEJAD, M.; BAKLAND, L.K. An animal model for the study of immunopathogenesis of periapical lesions. J Endod, v.4, n.9, p.273-7, Sept.1978.

68. TORABINEJAD, M.; EBY, W. C.; NAIDORF, I. Inflammatory and immunological aspects of the pathogenesis of human periapical lesions. J Endod, v.11, n.11, p.479-88, Nov. 1985.

69. VALE I. S. Visibilidade de algumas limas endodônticas por meio do sistema de imagem digital Digora e de três filmes radiográficos periapicais. Bauru, 2001. 221p. Tese (Doutorado em Radiologia) Faculdade de Odontologia de Bauru, Universidade de São Paulo.

70. VERSTEEG, K. H.; SANDERIK, G. C. H.; VAN GINKEL, F. C.; VAN DER STELT, P. F. Estimating distances on direct digital images and convencional radiographs. J Am Dent Assoc, v.128, n.4, p.439-43, April 1997.

71. WHITE, S. C. et al. Absence of radiometric differentiation between periapical cysts and granulomas. Oral Surg, v.78, n.5, p.650-4, Nov. 1994.

72. WESTPHALEN, V. P.; GOMES DE MORAES, I.; WESTPHALEN, F. H.; MARTINS, W. D.; SOUZA, H. Conventional and digital radiographic 
methods in the detection of simulated external root resorptions: a comparative study. Dentomaxillofac Radiol, v.33, n.4, p.233-5, Jul. 2004

73. YU, S. M.; STASHENKO, P. Identification of inflammatory cells in developing rat periapical lesions. J Endod, v.13, n.11, p.535-40, Nov. 1987. 
ABSTRACT 


\section{ABSTRACT}

Periapical lesions develop as a defensive response of periapical tissues due to bacterial infection and chemical, thermal and/or mechanical challenges. In the present study, the radiographic and microscopic aspects of the evolution of experimentally induced periapical lesions were analyzed with the purpose of delineating the disease progression. Rats were submitted to periapical lesion induction through the opening of the coronal pulp chamber of the left mandibular first molar followed by its exposure to oral cavity, promoting bacterial contamination. Samples were obtained from 3 to 180 days post periaical lesion induction. According to our results, induced periapical lesions exhibited a predominant polymorphonuclear (PMN) inflammatory infiltrate from day 3 until 60 days post induction, presenting a predominant mononuclear ( $\mathrm{MN}$ ) inflammatory infiltrate on further periods. Radiographic analysis revealed an evident increase in size of the periapical lesions between 7 and 14 days post induction periods, with a more discrete expansion on days 14 to 60 and stabilization at 60 and 120 days post induction. Correlating the different parameters observed, we may conclude that radiographic and microscopic aspects were agreeing since the first induction period analyzed (3 days). Still, the microscopic presence of cystic cavity as well as a radiographic localized bone rarefaction at the apical region of the left mandibular first molar were observed since 7 days post induction. Briefly, the active phase of periapical lesion evolution, presenting remarkable bone destruction, was related to the predominance of a PMN inflammatory infiltrate, whereas a MN inflammatory infiltrate was noted during the stabilization phase of the periapical induced lesions. Further, radiographic aspects of the induced periapical lesions in rats are similar to those observed in human inflammatory periapical disease; then, the rat model of periapical lesion induction may be considered a satisfactory model to the study of the evolution of these lesions. 